\title{
Petras Stankeras Policja litewska i sprawy (Vilnius) polskie na ziemiach litewskich w latach 1939-1944*
}

Stosunki polsko-litewskie na przestrzeni wieków to osobliwość, niezmiernie ciekawa i pouczająca, stanowiąca przykład budujących dróg i tragicznych bezdroży dwóch narodów. Przeszło pięćset lat współżycia polsko-litewskiego rozpada się na okresy, z których każdy zdumiewa swoją treścią. Litwini i Polacy w ciagu czterech stuleci mieszkali w jednym państwie, walczyli pod jednym sztandarem w trzech powstaniach przeciwko Rosji. Pierwsza połowa XX wieku to jeden z najciekawszych, ale jednocześnie najbardziej niechlubnych okresów we wspólnych dziejach obu narodów. Praktycznie od zakończenia pierwszej wojny światowej konflikt narastał na wszystkich płaszczyznach wzajemnych relacji. W ostatnich miesiącach przed inwazją Niemiec doszło, co prawda, do odprężenia w stosunkach politycznych, ale nie zmieniły się, uwidocznione w czasie wojny, negatywne nastroje społeczne.

Stosunki polsko-litewskie, układające się fatalnie od zarania niepodległości obu państw, w czasie drugiej wojny światowej dramatycznie się pogorszyły. Ogół społeczeństwa litewskiego powitał powrót Wilna do Litwy z entuzjazmem, tylko nieliczni patrzyli na ten sowiecki ,podarunek” z mieszanymi uczuciami. Chociaż konflikt między Litwą a Polską podczas okupacji niemieckiej nie był możliwy, to jednak przedwojenna wrogość nie wygasła. Konfrontacji nie udało się uniknąć także podziemnym ruchom oporu obu państw, chociaż oba miały tych samych wrogów - nazistowskie

* Redakcja czasopisma nie podziela niektórych tez i ocen autora artykułu. 
Niemcy i bolszewicką Rosję. Główną przyczyną sporu polsko-litewskiego była kwestia przynależności państwowej Wileńszczyzny. Społeczeństwo polskie mieszkające na tym obszarze patrzyło na Litwinów jak na okupantów. Jeszcze do tej pory niektórzy polscy historycy stawiają znak równości między nazistami i Litwinami.

W literaturze światowej nie brakuje opracowań na temat ostatniej wojny światowej XX wieku. Po 1945 roku ukazały się setki tysięcy książek i miliony artykułów o drugiej wojnie światowej, które, niestety, w ogromnej części były niedostępne na okupowanej przez Związek Radziecki Litwie. Potrzeba podjęcia badań nad historią policji litewskiej w latach 1939-1944 jest oczywista. Do tej pory historiografia polska nie dysponuje całościowym opracowaniem poświęconym temu zagadnieniu. Problem stosunków między policją litewską a mniejszością polską na Litwie nie był dotychczas rozpatrywany. Dziś, gdy od tych wydarzeń minęło ponad 60 lat oraz gdy nastąpił upadek znienawidzonego, totalitarnego systemu okupacyjnego stworzonego przez Związek Radziecki, istnieje możliwość rzetelnej i pełnej oceny dziejów policji litewskiej.

Chociaż Litwa i Polska przez stulecia stanowiły jeden organizm państwowy, to jednak świadomość historyczna współczesnych Polaków i Litwinów różni się diametralnie. Mimo że od tych krwawych wydarzeń minęło ponad 60 lat, niektórzy przedstawiciele obu narodów nadal nie chcą słyszeć o pojednaniu i wybaczeniu. Literatura historyczna, poświęcona zagadnieniu policji litewskiej oraz działaniom Polaków na historycznych terenach Litwy, przeważnie aktywności Armii Krajowej (AK), jest bardzo tendencyjna i jednostronna. Ocena działalności okręgu wileńskiego AK i jego stosunków z formacjami policji litewskiej wzbudza duże emocje. Polscy historycy nie są obiektywni i na kartach swych książek za wszelką cenę próbują „wybielić” AK, a litewskie instytucje samorządu i litewską policję ukazuja jako wroga numer jeden. Wiele z tych publikacji to bardzo cenne prace. Jednak, niestety, w niektórych fantazja autorów góruje nad prawdą historyczną. I o ile pisarzom można darować, że licentia poetica brała niekiedy górę nad obiektywizmem, o tyle ludziom uznającym swoje prace za „dokumentalne” nie można darować fałszowania historii. Dzisiaj, kiedy mamy pełną wolność i nieskrępowany dostęp do wszelkiej dokumentacji, nie możemy pozwolić na jakiekolwiek fałszowanie dziejów drugiej wojny światowej. Oto kilka przykładów.

Polski autor Roman Korab-Żebryk w swojej bardzo tendencyjnie napisanej książce pod dużo mówiącym tytułem Biała księga w obronie Armii 
Krajowej na Wileńszczyźnie ${ }^{1}$, pisząc o ,inspirowanych przez litewski Ruch obwinieniach AK"2, twierdzi, że policja niezależnej Litwy dość łatwo, prawie bez strat, wytrzymała okres władzy sowieckiej ${ }^{3}$ i po rozpoczęciu się wojny jej członkowie nadal pełnili służbę w odtworzonych przez rząd Juozasa Ambrazevičiusa ${ }^{4}$ formacjach: w policji bezpieczeństwa i policji kryminalnej oraz w batalionach policyjnych. Chociaż Tymczasowy Rząd Litwy (TRL) niedługo utrzymał się u władzy, stworzone przez niego, według autora, ,przestępcze infrastruktury litewskiej policji”, podporządkowane Gestapo oraz niemieckiej policji bezpieczeństwa, odegrały główną rolę w utrzymywaniu porządku na zajętych przez Niemców ziemiach. Roman Korab-Żebryk stawia znak równości między litewską policją kryminalną a Gestapo. Mówiąc o litewskich batalionach policyjnych, autor konstatuje, że od początku wojny w ciągu kilku miesięcy ich liczba osiagnęła 20 oddziałów. W sierpniu 1942 roku służyło w nich 8400 ludzi, w tym: 341 oficerów, 1772 podoficerów i prawie 6300 szeregowych. Niepozbawiona subiektywnych ocen jest także wydana w 1985 roku monografia tego autora ${ }^{6}$.

Mieszkający na Litwie Polak Jarosław Wołkonowski w monografii poświęconej działalności AK w okolicach stolicy Litwy - Wilna ${ }^{7}$ - twierdzi, że już 28 czerwca 1941 roku Niemcy rozbroili oddziały litewskich partyzantów w Kownie, same oddziały wzięli pod swoje dowództwo, likwidując przedtem sztab policji oraz główną komendanturę. Wkrótce z „kry-

${ }^{1}$ R. Korab-Żebryk, Biała księga w obronie Armii Krajowej na Wileńszczyźnie, Lublin 1991.

2 Ibidem, s. 4 okładki.

${ }^{3}$ W latach 1940-1941 w czasie okupacji sowieckiej represjonowano 887 litewskich policjantow, co daje 3\% wszystkich represjowanych mieszkancow Litwy. Z tej liczby 103 wywieziono na Syberię, 250 aresztowano i osadzono w więzieniu, 435 uwięziono w łagrach, 33 zamordowano na Litwie. Sposób represji wobec 77 policjantów litewskich nie jest jeszcze do końca wyjaśniony.

${ }^{4}$ Juozas Ambrazevičius - ur. 9.12.1903 r. W latach 1922-1927 studiował na uniwersytecie w Kownie na wydziale teologii i filozofii, później na uniwersytecie w Bonn. Profesor. W latach 1927-1943 z roczną przerwą nauczyciel w kowieńskim gimnazjum „Aušra”. 23.06-5.08.1941 - minister oświaty i tymczasowo pełniący obowiązki premiera Tymczasowego Rządu Litwy. Sumienny, szybko orientujący się polityk o twardym charakterze. Pod koniec wojny wyjechał do Niemiec, następnie do USA. Od 1952 r. redaktor miesięcznika „Darbininkas”, potem „I laisvę". Zmarł w 1974 r. w New Jersey.

${ }_{5}$ R. Korab-Żebryk, Biała ksiega, s. 12-13.

${ }^{6}$ Idem, Operacja wileńska AK, Warszawa 1985.

7 J. Wołkonowski, Okręg Wileński Zwiazku Walki Zbrojnej Armii Krajowej w latach 1939-1945, Warszawa 1996. 
minalnych przestępców oraz litewskich nacjonalistów" zaczęto tworzyć litewskie bataliony policyjne. Drugi batalion policji (dowódca - kapitan Aleksas Kazakevičius ${ }^{9}$ ) powstał w lipcu, a piąty - w sierpniu w Kownie (dowódca - kapitan Juozas Kriščiūnas ${ }^{10}$ ). Piszący bardzo niepochlebnie o Litwie i Litwinach autor zaznacza, że według litewskich źródeł powstało piętnaście batalionów litewskiej policji mających różne numery. Jarosław Wołkonowski twierdzi, że z dyslokowanych w Wilnie batalionów policji został sformowany Specjalny Oddział Wilna. Wkrótce, w listopadzie 1941 roku, ze szczątków starego wojska oraz policji litewskiej stworzono nową organizacje - Schutzmannschaften. W połowie 1942 roku w jej składzie służyło 16 tysięcy Litwinów: 6 tysięcy w jednostkach policji i 10 tysięcy w batalionach policji (Schuma-Bataillonen - pełna nazwa: Schutzmannschafts Bataillonen). Bez podania dowodów autor śmiało twierdzi, że „na skutek kolaboracji znacznej części [!? - P. S.] społeczeństwa litewskiego z hitlerowcami, ludność polska Wileńszczyzny znalazła się pod wpływem podwójnego terroru” "11, że ,administracja litewska gotowa była służyć każdemu, kto imponuje jej siłą"12. Jarosław Wołkonowski, żyjący w wolnym i niezależnym państwie litewskim, oczernia Litwę i ukazuje w fałszywym świetle jej historię, sugeruje nawet, że „Litwa została trzecim państwem, obok ZSRS i Niemiec hitlerowskich, które podzieliły między siebie terytorium II RP"'3 , nie wspominając o tym, że w rzeczywistości to Polska postąpiła w ten sposób z Litwą po pierwszej wojnie światowej. Na zakoń-

${ }^{8}$ Ibidem, s. 75.

9 Aleksandras Kazakevičius - kapitan, dowódca 4. kompanii Batalionu Odbudowy Wilna (VAT - Vilniaus atstatymo tarnyba), a od października 1941 r. dowódca wileńskiego 2. Batalionu Litewskiej Policji.

${ }^{10}$ Juozas Kriščiūnas - ur. 29.10.1899 r. w powiecie mariampolskim. Od 9.02.1919 r. jako ochotnik walczył z bolszewikami i Polakami. 18.12.1921 r. ukończył naukę wojskową i otrzymał pierwszy stopień oficerski. Od 23.11.1931 r. kapitan. W 1934 r. brał udział w puczu Voldemarasa, za co został zdegradowany do stopnia szeregowca i wydalony z wojska. Po ukończeniu studiów ekonomicznych na Uniwersytecie Witolda Wielkiego pracował w banku. 12.07.1940 r. aresztowany przez bolszewickich okupantów, lecz w czasie powstania czerwcowego 23.06.1941 r. wyzwolony. W czasie wojny od 28.08.1941 r. dowódca 5. Batalionu Policji Pomocniczej. 9.10.1941 r. otrzymał stopień majora, lecz z powodu choroby $26.04 .1942 \mathrm{r}$. został zwolniony ze służby. W 1943 r. dyrektor Departamentu Spraw Społecznych Kierownictwa Spraw Wewnętrznych, przewodniczący Głównego Komitetu Pomocy dla Litewskich Wojskowych i Ich Rodzin. Zmarł 17.11.1976 r. w Mainz (Niemcy).

11 J. Wołkonowski, Okręg Wileński Zwiazku Walki Zbrojnej, s. 7.

12 Ibidem, s. 81.

13 Ibidem, s. 10. 
czenie autor, przy każdej okazji traktujący „Litwę” i „Wileńszczyznę” jako oddzielne organizmy, nie zwracając uwagi na historyczne fakty, wyciaga bezkompromisowy wniosek, że „Litwini wykorzystali okupację niemiecką dla załatwienia swych narodowych celów: wyniszczenia elementu polskiego"14, zapominając [czy nie wiedząc - P. S.], że zgodnie z wcześniejszymi deklaracjami prezydent Litwy Antanas Smetona ogłosił neutralność wobec tego konfliktu. Należy podkreślić, jak trudno było prezydentowi dotrzymać słowa, gdyż wówczas zdobycie Wilna było tak łatwe jak nigdy wcześniej. Do zbrojnej interwencji namawiały ponadto Litwę różne grupy nacisku i Niemcy. Mimo to rząd litewski nie wystapił przeciwko ofierze hitlerowskiej agresji.

Zupełnie inaczej o swych rodakach i AK wypowiada się polski historyk Z. Siemaszko na łamach wydawanego w Paryżu miesięcznika „Zeszyty Historyczne" (nr 110 za 1995 rok). Autor pisze, że Polacy w czasie wojny współpracowali nie tylko z przedstawicielami Wehrmachtu, ale także z Gestapo, że gazeta wileńska „Goniec Codzienny” była wspólnym organem Niemców i AK itd.

Dnia 1 września 1939 roku hitlerowskie Niemcy napadły na Polskę. Skutki rozpoczętej wojny dotknęły Litwę już od pierwszych dni. Gdy państwo polskie 17 września zostało zaatakowane także przez Związek Sowiecki, już następnego dnia, 18 września, na Litwę zaczęli uciekać polscy wojskowi oraz ludność cywilna. Żołnierzy polskich zatrzymywano, rozbrajano i zamykano w obozach dla internowanych. Czyniąc to, Litwa postępowała według wymagań konwencji międzynarodowych. Znajdujący się na Litwie uchodźcy (ponad 26 tys.) byli traktowani zgodnie z normami prawa międzynarodowego, a także zgodnie ze specjalnie uchwaloną na Litwie Ustawą o obchodzeniu się z uchodźcami wojennymi i z innymi aktami prawnymi. Obozami dla uchodźców zarządzał komisariat administracji uchodźców wojennych. Internowani Polacy, w szczególności oficerowie, często wchodzili w konflikty z zarządem obozów, których zażegnanie wymagało interwencji policji litewskiej.

14 Ibidem, s. 81. 
Dnia 10 października 1939 roku został podpisany sowiecko-litewski układ o wzajemnej pomocy, w którym ZSRR zobowiązał się przekazać Litwie Wilno i obwód wileński - pas około $220 \mathrm{~km}$ o obszarze $6880 \mathrm{~km}^{2}$, co zwiększyło terytorium Litwy o 13\%. Liczba ludności tego terenu wynosiła 549 tys., w tym Polacy stanowili 321,7 tys., Żydzi 107,6 tys., Litwini 31,3 tys., reszta - to Rosjanie, Niemcy i inni. W mieście, po krótkim pobycie Sowietów, brakowało wszystkiego, nawet podstawowych produktów żywnościowych.

Na nową litewską władzę czekano z niecierpliwością. Dopiero 28 października 1939 roku oddziały wojsk litewskich wkroczyły do Wilna. Z Kowna i innych miast Litwy przybyły autobusy z licznymi grupami Litwinów, składającymi się przeważnie z młodzieży i szaulisów, do których dołączyła miejscowa ludność litewska. Wznoszono bramy triumfalne, dekorowano miasta litewskimi flagami. Większość Polaków zachowywała się biernie. Na początku Litwini zostali nawet życzliwie przyjęci przez mieszkańców - w końcu był to swego rodzaju ratunek przed Sowietami. Jednakże nie zorganizowano wyjścia młodzieży polskich szkół, a arcybiskup wileński Romuald Jałbrzykowski nie wywiesił flag litewskich na budynku kurii ani nie przywitał dzwonami wileńskich kościołów wkraczających Litwinów. Być może stało się to powodem późniejszego konfliktu między Kościołem a nową władzą.

Wojsko litewskie prezentowało się nie najgorzej: było porządnie umundurowane, wyposażone $\mathrm{w}$ dobrej jakości sprzęt, inaczej niż żołnierze radzieccy, których ubiór i uzbrojenie dawały niepochlebny osąd o całej Armii Czerwonej. W sumie mieszkańcy Wilna przyjęli Litwinów, jeżeli nie z wielkim entuzjazmem, to na pewno życzliwie i bez większych uprzedzeń, można powiedzieć - z rezerwą. Niemniej jednak już kilka dni później rozpoczęły się demonstracje polskości oraz uwidoczniła się działalność polskiego podziemia. Zaczęły tworzyć się organizacje zrzeszające Polaków, dążących do zachowania Wileńszczyzny jako terenów polskich oraz spodziewających się, że po wojnie stolica Litwy znowu będzie należała do Polski.

Za wojskiem litewskim na Wileńszczyznę wkroczyła 29 października policja litewska, która w okresie wojny była przedstawicielem i symbolem władzy litewskiej na terenie Litwy. W Kraju Wileńskim postanowiono urządzić 27 posterunków powszechnej policji, wśród nich 20 posterunków I rzędu i 7 II rzędu. Oprócz tego powstały dwa posterunki policji kolejowej - w Wilnie i w Nowych Święcianach. Na dowódcę litewskiej policji 
porządkowej w powiecie wileńskim został wyznaczony Vincas Remeikis ${ }^{15}$, a jego pomocnikami byli Antanas Iškauskas ${ }^{16}$ i Andrius Butas ${ }^{17}$. W Wilnie powstała także druga szkoła policji.

Ogromna koncentracja uchodźców w Wilnie i na Wileńszczyźnie stwarzała wiele problemów nowo powstałej administracji i policji litewskiej. Część uchodźców i żołnierzy uciekła z obozów internowania, wierząc w szybkie odtworzenie wielkiej Polski i dążąc do utrzymania Wilna w przyszłym państwie. Litwę uznawali oni za kraj nieprzyjazny i włączyli się do działalności antylitewskiej. Jednak w styczniu 1940 roku, po zlikwidowaniu przez litewską służbę bezpieczeństwa i policję kilku polskich organizacji podziemnych, ich aktywność bardzo osłabła. Takie działania władz litewskich były popierane przez społeczeństwo międzynarodowe, a nawet przez rząd polski na emigracji - stwarzało to pozytywny obraz Litwy na świecie.

W połowie czerwca 1940 roku Litwa została przyłączona do Związku Radzieckiego, co dla Wilna oznaczało drugą okupację - radziecką; przeważająca zaś część Wileńszczyzny bezprawnie należała już od września 1939 roku do radzieckiej Białorusi. Policja litewska po politycznej czystce przekształciła się w komunistyczną milicję.

15 Vincas Remeikis - ur. w 1901 r. w Jurborku. W latach 1920-1927 służył w wojsku litewskim. 11.04.1928 r. rozpoczął służbę jako podporucznik w policji granicznej Kraju Kłajpedzkiego. 30.08.1929 r. mianowany oficerem artylerii na okręcie ochrony morza „Prezidentas Smetona”. Od 1.02.1930 r. komisarz policji granicznej Kraju Kłajpedzkiego, od 1.11.1933 r. dowódca floty policji granicznej. $1.01 .1935 \mathrm{r}$. został naczelnikiem ochrony morza. Od 1.03.1936 r. pomocnik dowódcy policji granicznej Kraju Kłajpedzkiego. Od 1.04.1939 r. naczelnik szkoły policji w Kownie. Jesienią 1939 r. mianowany dowódcą policji porządkowej w Wilnie. Od 1.12.1941 do lipca 1943 r. dowódca policji powiatu wileńskiego. Od 1.12.1943 r. przeniesiony do sztabu policji i mianowany trzecim referentem policji. 1.03.1944 r. zwolniony ze służby w policji. Nagrodzony Orderem Witolda Wielkiego 5 stopnia oraz Medalem Niepodległości Litwy.

${ }^{16}$ Antanas Iškauskas - ur. 30.05.1898 r. w powiecie mariampolskim. Oficer litewskiego wojska, w różnych okresach był dowódcą policji kilku powiatów, pomocnikiem dowódcy policji miast i powiatów Kowna i Wilna. Członek organizacji „Żelazny Wilk”. W czasie wojny - dowódca powszechnej policji miasta Wilna i okręgu.

${ }^{17}$ Andrius Butas - ur. w 1896 r. Od 18.12.1921 do 29.10.1927 r. służył w wojsku. 18.01.1931 r. przyjęty do policji i mianowany naczelnikiem rejonu II rzędu policji granicznej w Ucianie. 1.04.1934 r. mianowany naczelnikiem rejonu I rzędu policji granicznej w Jeziorosach. 1.07.1936 r. mianowany dowódcą kowieńskiej rezerwy policji, od października $1939 \mathrm{r}$. na tym samym stanowisku w Wilnie. W listopadzie 1939 r. mianowany drugim pomocnikiem dowódcy policji w powiecie wileńskim. Do 30.11.1943 r. zastępca dowódcy policji w powiecie wileńskim, a od 1.12.1943 r. - dowódca. Nagrodzony Orderem Wielkiego Księcia Giedymina 5 stopnia. 
Po rozpoczęciu zbrojnej konfrontacji Rosji sowieckiej z Niemcami większość funkcjonujących w czasie wojny litewskich urzędów działała w interesie wszystkich mieszkańców Litwy, w tym także Polaków, unikając udzielania aktywnej pomocy niemieckiemu okupantowi. Jednak litewska policja znalazła się pod bezpośrednią kontrolą Niemiec. Na Litwie, gdzie przedwojenna armia została przeobrażona w sowieckie jednostki i w pierwszych dniach wojny poddała się Niemcom, proponowano Litwinom wybrać między batalionem Samoobrony a obozem dla jeńców wojennych. Nic dziwnego, że absolutna większość wybrała bataliony czy inne struktury policyjne. W czasie wojny wielu Litwinów pracowało w urzędach samorządu, służyło w policji i nie była to działalność przestępcza, gdyż pracowali oni w swoim kraju - na Litwie i jeśli to było możliwe, działali na korzyść Litwy, a nie niemieckiego najeźdźcy. Podczas wojny wszystkie siły polityczne Litwy, oprócz bolszewickich partyzantów i członków podziemia oraz polskiej AK, dążyli do odtworzenia niezależności Litwy, tylko stosowane przez nich metody działania były różne. W związku z tym trudno jest ocenić, które z nich miały na celu walkę o niepodległość, a które - kolaborację z Niemcami. Jednocześnie wśród Litwinów zdarzały się rzadkie przypadki przechodzenia od „kolaboracji” do jawnej i bezkompromisowej opozycji wobec Niemców (generał Povilas Plechavičius ${ }^{18}$ ).

Okres po napaści Niemiec na Związek Sowiecki - to czas szybkiego rozwoju organizacyjnego polskiego podziemia oraz podjęcia działalności dywersyjno-sabotażowej. Związek Walki Zbrojnej ${ }^{19}$ (ZWZ, od 14 lutego 1942 roku Armia Krajowa - AK) zmierzał zasadniczo do odtworzenia

${ }^{18}$ Povilas Plechavičius - ur. 1.02.1890 r. w Bukonciach, w powiecie Możejki. W czasie pierwszej wojny światowej ukończył szkołę kawalerii w Orenburgu i został oficerem. Przez cały czas wojny był na froncie, służył w piechocie, a najdłużej - w 5. pułku kawalerii, dowodził eskadronem i kompania, trzy razy był ranny. Walczył z bolszewikami, bermondtowcami oraz Polakami. Służbę ukończył w stopniu porucznika. Od maja 1921 r. dowódca 2. pułku kawalerii, od 1922 r. - major. W 1924 r. ukończył kursy wyższych oficerów i został wysłany do Akademii Sztabu Generalnego Czechosłowacji. Od 31.12.1926 r. inspektor kawalerii, a od 4.01.1927 r. również naczelnik sztabu generalnego. Od 28.02.1927 r. podpułkownik, latem 1927 r. został pułkownikiem. W okresie 11.08.1927-10.02.1929 naczelnik Sztabu Generalnego. Od 10.02.1929 r. generał lejtnant. W tym czasie przeszedł w stan spoczynku. 15.06.1940 r., po sowieckiej okupacji Litwy, wycofał się do Niemiec. W czasie wojny - oficer łącznikowy litewskich batalionów policyjnych przy dowodztwie niemieckiej policji powszechnej, w 1944 r. główny organizator i dowódca Miejscowej Drużyny Litwy. Po rozwiązaniu LVR więzień obozów koncentracyjnych w Salaspilsie, a później w Stutthofie. Po wojnie od 1949 r. mieszkał w USA, gdzie 19.12.1973 r. zmarł w Chicago.

19 26-27.09.1939 r. powstała organizacja Służba Zwycięstwu Polski, która 13.11.1939 r. została przeorganizowana w Związek Walki Zbrojnej. 
Polski przedwrześniowej - do oderwania Kraju Wileńskiego od Litwy i przyłączenia go do Polski, zamierzał realizować plan emigracyjnego rządu polskiego w Londynie odbudowania piłsudczykowskiej Polski „od morza do morza". W działalności AK brali udział nie tylko miejscowi Polacy, ale także przysłani z Polski i Londynu. W marcu 1943 roku został zapoczątkowany polski ruch partyzancki na Wileńszczyźnie - powstały leśne oddziały partyzanckie AK, a od wiosny 1944 roku duże jednostki partyzanckie - brygady i dywizje, sformowane w ramach tzw. OSZ (Odtworzenie Sił Zbrojnych). Okoliczności towarzyszące narodzinom partyzanckich jednostek AK miały zasadniczy wpływ na kształtowanie się stosunków pomiędzy partyzantką sowiecką a polską, lecz próby zawarcia porozumienia między obiema stronami nie powiodły się. Faktycznie AK to przykład armii kolonialnej na terenie Litwy, Białorusi i Ukrainy.

Początkowo, w pierwszych dniach wojny, najwyższą instytucją litewskiej policji bezpieczeństwa i policji kryminalnej był Departament Bezpieczeństwa Państwowego (DBP) (Kowno, prospekt Witolda 67), formalnie przydzielony do Ministerstwa Spraw Wewnętrznych TRL. Najpierw jego dyrektorem był Vytautas Reivytis ${ }^{20}$, potem - Stasys Čenkus ${ }^{21}$. Później zamiast DBP Niemcy utworzyli Wydział Litewskiej Policji Bezpieczeństwa (Litauische Abteilung) przy dowódcy niemieckiej policji bezpieczeństwa i SD na Litwie. Jego kierownikiem został S. Čenkus. W rzeczywistości wydział ten działał dość samoistnie. W czasie wojny dowództwo niemiec-

${ }^{20}$ Vytautas Reivytis - ur. 19.07.1901 r. Urzędnik policji niepodległej Litwy. W 1930 r. oddelegowany do Niemiec na naukę jujitsu. Po powrocie z Niemiec przez długi czas wykładał w kowieńskiej szkole policji zapasy sportowe, a do 1940 r. był naczelnikiem policji kolejowej w Kibartach. W 1940 r. wyjechał do Niemiec. Na początku wojny - dyrektor Departamentu Bezpieczeństwa, a później, od 26.07.1941 do 1944 r. dyrektor Departamentu Policji, od 15.09.1941 r. jednocześnie oficer łącznikowy litewskiej policji przy sztabie dowódcy niemieckiej policji porządkowej na Litwie, od września 1941 r. naczelnik sztabu litewskiej policji powszechnej. Wydawca - główny redaktor organu prasowego policji „Policija”. 9.01.1943 r. nagrodzony Krzyżem Zasług Wojskowych z Mieczami II klasy. W 1944 r. wycofał się do Niemiec. Po wojnie pracował w 2 wydziale angielskiej służby wywiadu w Niemczech. W 1951 r. przeniósł się do Szkocji.

${ }^{21}$ Stasys Čenkus - ur. w 1901 r. Przed wojną- urzędnik policji Litwy, pułkownik. W latach 1933-1939 pracował jako naczelnik okręgu mariampolskiego Departamentu Bezpieczeństwa, w latach 1939-1940 - naczelnik okręgu wileńskiego. W 1940 r. w czasie sowieckiej okupacji Litwy udał się do Niemiec i pracował w Abwehrze. W czasie wojny - dyrektor Departamentu Bezpieczeństwa Państwowego, potem - kierownik Wydziału Litewskiej Policji Bezpieczeństwa przy dowódcy niemieckiej policji bezpieczeństwa i SD na Litwie. W 1944 r. wyjechał do Niemiec, po wojnie - do USA. Żył w Nowym Jorku, pracował jako tajny urzędnik służby imigracyjnej USA i Federalnego Biura Śledczego. 
kie nie stawiało przed litewską policją bezpieczeństwa żadnych zadań ${ }^{22}$. Główną jej funkcją była walka z komunistycznym i polskim podziemiem oraz przestępcami kryminalnymi. Za pośrednictwem tajnej policji litewskiej, mającej do dyspozycji całą rzeszę konfidentów rekrutujących się głównie spośród Litwinów, dokonywano penetracji poszczególnych grup społeczeństwa polskiego.

Terytorium Litwy było podzielone na sześć okręgów policji bezpieczeństwa i policji kryminalnej (Kowno, Wilno, Szawle, Poniewież, Mariampol i Wiłkomierz ${ }^{23}$, a okręgi - na rejony. W każdym okręgu mieścił się zarząd policji bezpieczeństwa, który zazwyczaj był podzielony na siedem wydziałów (komisariatów); wydział piąty demaskował nielegalną działalność polskich organizacji, przeprowadzał aresztowania, rewizje i przesłuchania, miał agenturalną sieć.

Zarząd kowieńskiego okręgu litewskiej policji bezpieczeństwa (naczelnik Albinas Čiuoderis ${ }^{24}$ ) w swym składzie miał III komisariat, pod nazwą „Polacy”, jego kierownikiem był Volodkevičius, pracowało w nim 3-4 urzędników. Głównymi funkcjami polskiego komisariatu były: śledzenie aktywności konspiracyjnych organizacji polskich, w tym przede wszystkim AK, aresztowanie i przesłuchiwanie schwytanych Polaków, rekrutowanie agentów.

W skład wileńskiego okręgu litewskiej policji bezpieczeństwa wchodziło dziesięć rejonów (Ejszyszki, Mejszagoła, Troki, Koszedary, Święciany, Podbrodzie, Jaszuny, Nowa Wilejka, Oszmiana, Świr), a miasto Wilno było podzielone na siedem rejonów ${ }^{25}$. Z początku okręg ten był nazywany wileńskim okręgiem Litewskiej Pomocniczej Państwowej Policji Bezpieczeństwa (naczelnik Norbertas Mikšys ${ }^{26}$ ) i składał się z pięciu wydziałów: śledczego, informacyjnego, agenturalnego, operacyjnego i spe-

22 Twierdzenie A. Lileikisa. Zob. „Respublika”, 17 VII 1996, nr 192 (1907).

${ }^{23}$ LCVA (Lietuvos Centrinis Valstybès Archyvas), f. R-972, ap. 1, t. 2, b. 534, 1. 40.

${ }^{24}$ Albinas Čiuoderis - do czasu okupacji bolszewickiej kierował Wydziałem Specjalnym Departamentu Bezpieczeństwa. W czasie wojny - naczelnik kowieńskiego okręgu litewskiej policji bezpieczeństwa.

25 A. Bubnys, A. Lileikio veikla liudija archyvai, „Respublika”, 25 VIII 1996, nr 225 (1940).

${ }^{26}$ Norbertas Mikšys - ur. w 1897 r. Do wojny - kierownik Wydziału Agenturalnego Kowieńskiej Policji Kryminalnej. W lipcu 1941 r. - kierownik Wydziału Politycznego Wileńskiej Policji Bezpieczeństwa. Od 08.1941 r. naczelnik okręgu wileńskiego Litewskiej Pomocniczej Policji Bezpieczeństwa. 
cjalnego ${ }^{27}$. W okręgu pracowali starsi urzędnicy oraz urzędnicy I, II i III rzędu - w lutym 1942 roku było ich $103^{28}$. Zarządem wileńskiego okręgu litewskiej policji bezpieczeństwa w latach 1941-1944 kierował Aleksandras Lileikis ${ }^{29}$. Nie był on samodzielnym kierownikiem policji litewskiej: wszystko było kontrolowane przez wydział niemieckiej policji bezpieczeństwa i SD (Aussendienstelle Sipo - Sicherheitspolizei und SD Wilna). Zarząd wileńskiego okręgu litewskiej policji bezpieczeństwa w swym składzie miał między innymi komisariat Polaków (kierownik Aleksandras Babravičius). Litewskiej bezpiece było szczególnie ciężko pracować w okręgu wileńskim. Działały tu silne organizacje Polaków i bolszewików, a poczynając od lata 1943 roku - duże bandy sowieckich partyzantów, ugrupowania AK i inni. Od 1942 roku głównym kierunkiem działania litewskiej policji bezpieczeństwa okręgu wileńskiego była walka z rosnącym podziemiem komunistycznym i polskim. W dokumencie Głównego Urzędu Bezpieczeństwa Rzeszy (RSHA) o wydarzeniach na Wschodzie odnotowano, że w Wilnie od 16 lutego do 21 marca 1942 roku aresztowano 319 osób, 137 aresztowanych rozstrzelano, wśród nich: 73 Żydów, 23 komunistów, 14 członków polskiego podziemia, 20 fałszerzy dokumentów i 7 szpiegów $^{30}$.

Obecnie w niepodległej Litwie ocena Saugumy jest niejednoznaczna. Pozytywnie jest oceniana jej rola w zwalczaniu komunistów i sowieckiej

27 LCVA, f. R-681, ap. 2, b. 32, 1. 1-2.

${ }^{28}$ Ibidem, f. R-972, ap. 1, b. 535, 1. 138.

${ }^{29}$ Aleksandras Lileikis - ur. 10.06.1907 r. w Poprudziach. Urzędnik państwowej policji bezpieczeństwa Litwy. W latach 1937-1939 pracował jako zastępca naczelnika policji bezpieczeństwa okręgu mariampolskiego, w 1939 r. przeniesiony do okręgu wileńskiego. W 1940 r. wycofał się do Niemiec. W czasie wojny od sierpnia 1941 do 1944 r. naczelnik okręgu wileńskiego litewskiej policji bezpieczeństwa. Brał aktywny udział w tajnym antynazistowskim ruchu litewskim. Po wojnie wyjechał do USA i w 1976 r. otrzymał obywatelstwo amerykańskie. 2.05.1995 r. generalna prokuratura Litwy założyła mu sprawę karną. W $1996 \mathrm{r}$. został oskarżony przez rząd USA o to, że „brał udział w masowych mordach Żydów na Litwie". Straciwszy obywatelstwo USA, 18.06.1996 r. wrócił na Litwę. Oskarżony o prześladowanie mieszkańców cywilnych podczas drugiej wojny światowej. Przez międzynarodowe organizacje żydowskie i przez prokuratorów USA bezkompromisowo jeszcze przed sądem ogłoszony przestępcą wojennym, chociaż w jego sprawie nie ma ani jednego obiektywnego dowodu na wydawanie pisemnych rozkazów mordowania osób żydowskiego pochodzenia. Litwa poddała się naciskom organizacji żydowskich i międzynarodowych, rozpoczynając proces sądowy bez osobistego udziału oskarżonego, a tylko z jego adwokatem. Oskarżony zmarł na Litwie 26.09.2000 r.

${ }^{30}$ A. Bubnys, Lietuviu saugumo policija ir holokaustas (1941-1944), „Genocidas ir rezistencija”, 2003, nr 1 (13). 
partyzantki, natomiast zdecydowanie negatywnie udział w prześladowaniu i mordowaniu Żydów. Nie ma porozumienia w sprawie działań Saugumy wobec polskiego ruchu oporu, gdyż wielu Litwinów uważa, że AK prowadziła działalność przestępczą przeciwko ludności litewskiej. W Polsce Sauguma jest postrzegana negatywnie - jako formacja kolaboracyjna, ściśle współpracująca $\mathrm{z}$ hitlerowcami oraz prześladująca i mordująca Polaków, zwłaszcza zamieszkujących Wileńszczyznę.

Sprawami polskimi na terenie Litwy aktywnie zajmowali się także Niemcy. Niemiecka służba bezpieczeństwa, wkraczając na teren Wileńszczyzny, była bardzo słabo zorientowana w sytuacji. Dopiero na miejscu sporządzono listy osób podejrzanych o wrogą działalność, w czym pomocna okazała się litewska policja bezpieczeństwa, która udostępniała Niemcom wcześniej przygotowane listy proskrypcyjne i prowadziła wstępne dochodzenia przekazywane później niemieckiej policji bezpieczeństwa. Wileński wydział Sicherheitspolizei i SD spełniał istotną funkcję i wyróżniał się wielkością. Jesienią 1943 roku w jego składzie działał pododdział IVE, zajmujący się kontrwywiadem (politycznym i ekonomicznym) oraz polskim ruchem oporu (kierownik SS-hauptscharführer Leopold Taiban).

W wypełnianiu obowiązków litewskiej policji porządkowej bezpłatnie pomagali honorowi policjanci ${ }^{31}$. Od początku wojny do 1 października 1943 roku było ich $7740^{32}$. Kompletowanie honorowej policji odbywało się zgodnie ze specjalnie zatwierdzonym regulaminem i instrukcją ${ }^{33}$. Pierwszy radca generalny i generalny radca do spraw wewnętrznych Komisariatu Generalnego Litwa generał Petras Kubiliūnas ${ }^{34}$, w porozumieniu z komi-

\footnotetext{
${ }^{31}$ LCVA, f. R-659, ap. 1, b. 56, 1. 2-3.

32 Ibidem, f. R-683, ap. 2, b. 13, 1. 102.

33 Podpisany przez V. Reivytisa 6.07.1942 r., okólnik, ibidem, f. R-691, ap. 1, b. 20, 1. 328.

${ }^{34}$ Petras Kubiliūnas - ur. 16.05.1894 r. w Tataryszkach, w rejonie rakiszskim. W 1914 r. ukończył Wileńską Szkołę Wojskową, służył w łotewskim pułku wojska carskiego. W 1919 r. powrócił na Litwę, był dowódcą batalionu wojska litewskiego, pomocnikiem dowódcy pułku. W 1920 r. organizował pułk pograniczny i dowodził ochroną północno-zachodniej granicy Litwy. Od 1922 r. pułkownik. W 1925 r. ukończył wyższe kursy wojskowe w Kownie, akademię wojskową w Pradze. 10.02.1929-7.06.1934 r. naczelnik sztabu generalnego, pełnił jednocześnie obowiązki dowódcy wojska, od 1932 r. generał lejtnant wojska litewskiego. Członek organizacji „Żelazny Wilk”. Brał udział w puczu 7.06.1934 r. W październiku 1934 r. wypędzony z wojska i skazany na śmierć, lecz wkrótce wyrok zamieniono na dożywocie. W 1937 r. A. Smetona go zwolnił. Prowadził swoje gospodarstwo. 31.07.1940 r. za działalność kontrrewolucyjną aresztowany przez sowieckich okupantów, był przesłuchiwany do powstania czerwcowego $1941 \mathrm{r}$. W czasie wojny - pierwszy generalny radca i generalny radca spraw
} 


\section{sarzem Komisariatu Generalnego Litwa dr. Adrianem Theodorem von Rentelnem $^{35}$ oraz z dowódcą SS i policji na Litwie SS-brigadeführerem i generałem majorem policji Hermannem Harmem ${ }^{36}$, 15 września 1943}

wewnętrznych Komisariatu Generalnego Litwa. Założyciel i przywódca Partii Litewskich Nacjonalistów (LNP - Lietuviu nacionalistu partija). W 1944 r. wycofał się do Niemiec, gdzie w październiku 1945 r. w mieście Holstein w angielskiej strefie Niemiec został tajnie schwytany, aresztowany przez sowiecki wywiad i wywieziony do ZSRR. Wojskowe kolegium Sądu Najwyższego Związku Sowieckiego 25.07.1946 r. skazało go na karę śmierci. Wyrok wykonany rozstrzelaniem 22 sierpnia tego samego roku w Moskwie.

${ }^{35}$ Adrian Theodor von Renteln - ur. 15.09.1897 r. w Hoczi (Rosja). Doktor filozofii i ekonomii. Ukończył gimnazium w Rydze. Po rewolucji bolszewickiej wrócił do Niemiec, gdzie w latach 1920-1924 studiował ekonomię polityczną i prawo gospodarcze na uniwersytetach w Berlinie i Rostocku. Aktywny dziennikarz. Po rosyjsku mówił nie gorzej niż po niemiecku i uważał się za eksperta od problemów wschodnich. Od 1928 r. członek NSDAP, a od 1929 r. członek SA. Nagrodzony złotą odznaką NSDAP. Od 1929 r. kierownik Związku Nauczycieli Narodowosocjalistycznych, od 1929 do 15.06.1932 r. przewodniczący Narodowosocjalistycznego Związku Uczniowskiego. W okresie 30.10.1931-16.06.1932 dowódca organizacji „Hitlerjugend”, jednocześnie kierownik Narodowosocjalistycznego Związku Studentów. 16.06.1932 r. przeniesiony do Wydziału Ekonomiczno-Politycznego NSDAP. Od 1932 r. kierownik Narodowosocjalistycznego Związku Bojowego (Kampfbundes des gewerblichen Mittelstandes). Od 1933 r. deputat Reichstagu z Poczdamu. W latach 1933-1935 przewodniczący Urzędu Gospodarki i Handlu Niemiec, przewodniczący Wyższej Izby Dyscyplinarnej Niemieckiego Frontu Pracy (DAF - Deutsche Arbeitsfront), kierownik Instytutu Ekonomiki Stosowanej i kierownik Urzędu Rzemiosł i Handlu w systemie kierownictwa NSDAP w Rzeszy. Jednocześnie kierował Głównym Urzędem Handlu i Rzemiosł w Centralnym Biurze DAF. Prezydent Związku Niemcy-Belgia. Od 6.01.1934 r. naczelnik sztabu Niemieckiego Frontu Pracy. W okresie 28.07.1941-1944 generalny komisarz Litwy. Dostał się do niewoli, przekazany władzom sowieckim, skazany na karę śmierci i w 1946 r. powieszony.

${ }^{36}$ Hermann Harm - ur. 30.09.1894 r. w rodzinie kolejarza. Przed wojną studiowal elektronikę. W czasie pierwszej wojny światowej służył w artylerii, odznaczony Krzyżem Żelaznym II i I klasy, otrzymał stopień porucznika. W 1919 r. zostawił służbę wojskową i pracował w rolnictwie. Od 1.02.1930 r. członek NSDAP (nr 204 385), od 1.08.1930 r. członek SA, od grudnia 1931 r. członek SS (nr 21 342). 1.02.1932 r. otrzymał pierwszy oficerski stopień SS - untersturmführer. Po dwóch miesiącach 5 kwietnia stał się SS-hauptsturmführerem. Od lutego do grudnia 1932 r. dowodził 40. pułkiem SS, za co 24 grudnia otrzymał stopień SS-sturmbannführera. Do 10.06.1933 r. pełnił obowiązki dowódcy 4. pułku SS. W tym samym czasie od 20.03 do 2.12.1933 r. pełnił obowiązki naczelnika sztabu okręgu SS „Północ”. 23.06.1933 r. otrzymał kolejny stopień SS-obersturmbannführera, a po kilku miesiącach (30 listopada) - SS-standartenführera. Od 15.12.1933 do 20.03.1935 r. dowódca XIV okręgu SS. 20.04.1934 r., w związku z urodzinami A. Hitlera, otrzymał stopień SS-oberführera. Od 1935 do kwietnia 1937 r. kierownik sztabu w Głównym Urzędzie Ras i Osadnictwa SS (RuSHA). Od 13.09.1936 r. - SS-brigadeführer i generał major policji. W okresie kwiecień 1937-czerwiec 1938 zastępca kierownika Głównego Urzędu Sądu SS. 15.05.1939 r. został naczelnikiem sztabu głównego okręgu SS „Północ” i te obowiązki pełnił do 1.07.1942 r. W okresie 1.08-4.10.1942 dowódca SS i policji Dnepropetrowska. W 1943 r. przeniesiony na Litwę i od 2.07.1943 do 8.04.1944 r. pełnił obowiązki dowódcy SS i policji Komisariatu 
roku ogłosił reorganizację istniejącej honorowej policji w Miejscowe Oddziały Samoobrony (Vietiniai savisaugos büriai - VSB) i zatwierdził zasady ich formowania ${ }^{37}$ liczące dziesięć punktów. Głównym celem VSB była ochrona mienia i życia mieszkańców Litwy, a także walka z bandytyzmem elementów sowieckich, spadochroniarzami wroga, szpiegami, terrorystami, zbiegłymi jeńcami wojennymi. Warto zwrócić uwagę na to, że w żadnym dokumencie organizacyjnym VSB nie było wzmianki na temat walki z podziemiem polskim i jego siłą zbrojną - AK. W ówczesnej sytuacji zadziałała chyba pragmatyczna polityka Niemców, którzy nie chcieli, by rozgorzał zbrojny konflikt między Litwinami i Polakami. Zmniejszając liczbę pracowników w urzędach i posterunkach policji, dyrektor Departamentu Policji V. Reivytis 7 lutego 1944 roku polecił dowódcom ożywić bezpłatną (honorową) policję i aktywnie posługiwać się nią. Nie była ona odpowiednio wyszkolona, więc spełniała jedynie funkcje pomocnicze. Tylko w niektórych powiatach Litwy pod koniec wojny policja honorowa była używana do walki z partyzantami polskimi i sowieckimi ${ }^{38}$.

Warto zwrócić uwagę na fakt, że szerzeniem idei szowinistycznych w szczególności zaznaczyli się polscy reakcyjni nacjonaliści, którzy w Wilnie dość powszechnie działali w wielu niemieckich urzędach, a w niektórych miejscowościach obwodu wileńskiego zakładali lokalne „organa samorządu". Ich działalność była skierowana przeważnie przeciwko tym, którzy dążyli do odtworzenia niezależnego państwa litewskiego ze stolicą w Wilnie. Historyczne prawo Litwinów do tego miasta traktowali jako „agresje”".

Chociaż działacze polskiego podziemia oraz partyzanci AK deklarowali swą przynależność do koalicji antyhitlerowskiej i ich celem była walka $\mathrm{z}$ niemieckim okupantem, to $\mathrm{w}$ tym samym czasie utrzymywali kontakty z przedstawicielami niemieckich służb bezpieczeństwa i władz administracyjnych na terenie Litwy. W powiecie wileńskim niemiecka admini-

Generalnego Litwa. Na początku 1944 r. razem z generałem P. Plechavičiusem organizował Miejscową Drużynę Litwy. Po wyjeździe z Litwy, do listopada 1944 r. pełnił odpowiedzialne obowiązki na Ukrainie. Od 1.11.1944 r. do końca wojny tymczasowo zastępował wyższego dowódcę SS i policji głównego okręgu SS „Alpenland”. Za zasługi dla ruchu nazistowskiego odznaczony srebrnym znaczkiem NSDAP. H. Himmler nagrodził go Honorową Szpadą SS i Pierścieniem SS. Wychował tylko jedną córkę. Po wojnie mieszkał w RFN-ie i zmarł 28.11.1985 r. w Hartenholm.

${ }^{37}$ LCVA, f. R-660, ap. 2, b. 1, 1. 2; ibidem, f. R-1018, ap. 1, b. 96, 1. 141.

${ }^{38}$ Ibidem, f. R-409, ap. 1, b. 23, 1. 32. 
stracja opierała się bardziej na Polakach niż na Litwinach ${ }^{39}$. Dnia 4 sierpnia 1941 roku komisarz Hans Hingst ${ }^{40}$ wezwał kierowników Komitetu Obywatelskiego miasta Wilna i obwodu Stasysa Žakevičiusa ${ }^{41}$, Vladasa Jurgutisa i innych i oświadczył im, że w Kraju Wileńskim Litwini są mniejszością narodową, dlatego na kierownicze stanowiska w mieście trzeba mianować więcej Polaków ${ }^{42}$. W powiatach, w których większość mieszkańców stanowili Polacy, tworzono polską policję pomocniczą ${ }^{43}$. Taki „samorząd” polscy nacjonaliści od 8 sierpnia 1941 roku tworzyli na przykład w Druskiennikach, gdzie przejęli kontrolę nad urzędem burmistrza, nad policją bezpieczeństwa i policją pomocniczą ${ }^{44}$. Gdy w kwietniu 1942 roku nastąiło przyłączenie terenów Oszmiany, Świru i Ejszyszek do Komisariatu Generalnego Litwa, polska policja pomocnicza stawiła opór $^{45}$. Natychmiast skierowano tam 117 kowieńskich policjantów w celu przywrócenia porządku ${ }^{46}$.

Między funkcjonariuszami litewskiego samorządu a polskim podziemiem i AK dość długo nie dochodziło do zdecydowanej konfrontacji, lecz konflikt nieustannie dojrzewał. Zwrócił na to uwagę dowódca niemieckiej policji porządkowej (powszechnej) w Wilnie SS-sturmbannführer

39 Итоги второй мировой войны, Москва 1957, s. 502.

${ }^{40}$ Hans Hingst - ur. 3.08.1895 r. w Hachelhausen (okręg Harz). W Monachium pracował jako fryzjer. Kreisleiter NSDAP, od września 1939 r. służył w Łodzi. SA-sturmbannführer. Od 28.07.1941 r. komisarz miasta Wilno. Krążyły pogłoski, że jego żona była Polką, dlatego sympatyzował z Polakami, w szczególności z żołnierzami Armii Krajowej. 4.07.1944 r. bez zgody generała G. Poela samochodem uciekł z Wilna do Kowna. Wskutek błyskawicznego rozwoju sytuacji jego dezercja nie pociagnęła za sobą konsekwencji. 1 sierpnia został ewakuowany z resztą swego urzędu do Neumunster (Holstein). Jego powojenne losy nie są znane.

${ }^{41}$ Stasys Žakevičius - ur. 22.04.1908 r. Studia polityczne ukończył w Paryżu oraz w Harvardzie. Prawnik, profesor Uniwersytetu Wileńskiego. Aktywny członek Litewskiego Frontu Aktywistów. W 1941 r. przewodniczący Komitetu Obywatelskiego miasta Wilna i obwodu. W 1944 r. wyjechał do Niemiec. Po wojnie służył w wywiadzie Anglii, potem wyjechał do USA, gdzie przybrał nazwisko Žymantas. Zmarł w 1973 r. w Los Angeles.

42 A. Bubnys, Lietuviu ir lenku pasipriešinimo judejimai 1942-1945 m.: sqsajos ir skirtumai, „Genocidas ir rezistencija”, 2003, nr 1 (13).

43 „Военно-исторический журнал”, 1990, nr 6, s. 30.

${ }^{44}$ LMAB RS (Lietuvos mokslų akademijos biblioteka - Rankraščių skyrius), f. 169, 1. 64-65.

45 J. Wołkonowski, Okręg Wileński Zwiqzku Walki Zbrojnej, s. 80.

${ }^{46}$ M. Wardzyńska, Polityka narodowościowa Trzeciej Rzeszy w Generalnym Komisariacie Litwy, „Pamięć i Sprawiedliwość”, 1996, t. 38, s. 114. 
i major policji Maximilian Stötzel ${ }^{47}$. W swym piśmie zaznaczył, że litewscy żołnierze jednostek Samoobrony z byle powodu używają broni palnej. Najczęściej konflikty zdarzają się z Polakami ${ }^{48}$. Takie postępowanie Litwinów wywołuje krytykę społeczeństwa oraz żołnierzy niemieckich.

Już na początku swego panowania Niemcy starali się wykorzystać sprzeczności między Litwinami i Polakami. W szczególności uwidoczniło się to w rywalizacji urzędników Komisariatu Rzeszy i komendantów Wehrmachtu o kontrolę nad terytorium na południowy wschód od linii Druja-Malaty-Rumszyszki-Wisztyniec. W 1941 roku dowództwo ZWZ usunęło z urzędu wyznaczonego przez Niemców burmistrza Święcian, a litewskich policjantów z Solecznik i Dziewieniszek zwolniło z pracy i na ich miejsce wyznaczyło policjantów Polaków. Uwzględniając to, że konflikt polsko-litewski wciąż narastał, na mocy rozporządzenia władz niemieckich polska policja pomocnicza została rozwiązana.

W 1942 roku Niemcy podjęli kolejną próbę poróżnienia Litwinów i Polaków, zamierzając wysiedlić „statystycznych Polaków” ze wschodniej Litwy. Decyzję tę musieli zatwierdzić litewscy urzędnicy, a wykonać ją - litewscy policjanci. Niemcy, wykorzystując litewską policję bezpieczeństwa oraz żołnierzy litewskich batalionów policyjnych do walki z polskim podziemiem i ruchem oporu, ostatecznie skomplikowali stosunki polsko-litewskie.

Dnia 22 stycznia 1943 roku w stolicy komisariatu Ostland - Rydze - odbyła się narada komisarzy generalnych i okręgowych ${ }^{49}$. Okręgowy komisarz Wilna H. Hingst wygłosił referat „Polacy w administracji i gospodarce” (Die Polen in Verwaltung und Wirtschaft), w którym twierdził, że niemiecka administracja, wykonując zarządzenia ministra Alfreda Rosenberga ${ }^{50}$,

${ }^{47}$ Maximilian Stötzel - od 1.05.1939 r. członek SS (nr 323 892), SS-sturmbannführer i major policji. Od 15.09.1941 r. dowódca policji porządkowej (powszechnej) w Wilnie.

${ }^{48}$ LCVA, f. R-660, ap. 2, b. 234, 1. 1.

49 A. Bubnys, Vokiečiu okupuota Lietuva (1941-1944), Vilnius 1998, s. 151.

${ }^{50}$ Alfred Rosenberg - ur. 12.01.1893 r. w Rewlu (Tallinie), syn szewca i Estonki. Od 1910 r. studiował architekturę w Wyższej Szkole Technicznej w Rydze, w 1915 r. razem ze szkołą ewakuowany do Moskwy. W 1917 r. otrzymał dyplom architekta. W październiku 1917 r. w Moskwie, sympatyzował z bolszewikami. W lutym 1918 r. wrócił do Tallina, gdzie próbował wstąpić do Freikorps, lecz nie został przyjęty jako „ruski”. W końcu 1918 r. z pierwszymi eszelonami uciekinierów dostał się do Monachium. Po przyjeździe do Berlina utrzymywał kontakty z „białą” emigracją rosyjską, m.in. z ukraińskim hetmanem Skoropadskim i Niemirowiczem-Danczenko. W końcu 1919 r. D. Eckart wciaggnął go do „Związku Tuhle” i zbliżył z A. Hitlerem. Od 1919 r. członek NSDAP (nr 126), w 1920 r. powtórne członkostwo w NSDAP (nr 625). Judaizm i bolszewizm uważał za największe zło na świecie. W $1920 \mathrm{r}$. 
prowadzi politykę osłabiania wpływu Polaków. Większość ważnych stanowisk, związanych z administracją i gospodarką, zajmowali Litwini, lecz brakowało im sił do całkowitego usunięcia Polaków. W związku z taką polityką bardzo wzrosła działalność polskiego podziemia. Hingst wskazał, że 80-90\% rzemieślników i robotników w Wilnie stanowią Polacy, dlatego wobec do nich trzeba prowadzić łagodniejszą politykę.

Niemiecka administracja podtrzymywała i dobrze uzbrajała polskich partyzantów AK, którzy grasowali w powiecie święciańskim, w litewskich miejscowościach terroryzowali i zabijali Litwinów oraz napadali na policję litewską ${ }^{51}$. Wielu litewskich policjantów zginęło z rąk polskich partyzantów, aktywnych nie tylko w Kraju Wileńskim, m.in. zastrzelili oni policjanta nadzoru cen Zaranka, funkcjonariusza policji kryminalnej

wydał antysemickie prace Ślad Żydów w zmianach czasu oraz Niskie morale w Talmudzie. W 1921 r. redaktor naczelny „Völkischer Beobachter” oraz pisma „NS Monatshefte”. Brał udział w puczu 9.11.1923 r., ukrywał się i nie był sądzony. W czasie gdy A. Hitler siedział w więzieniu, założył Wielkoniemiecką Wspólnotę Robotniczą, w której znalazła się większość członków zabronionej NSDAP. W 1929 r. założył Związek Walki o Niemiecką Kulturę (Kampfbund für deutsche Kultur). W 1930 r. wydał książkę Der Mythus des zwanzigsten Jahrhunderts („Mit XX wieku”), za którą 30.01.1937 r. otrzymał Narodową Premię Niemiec. Ta książka stanowiła drugą po Mein Kampf biblię ruchu narodowosocjalistycznego. Zajmował się również malowaniem krajobrazów, reprodukcjami zdobił niektóre z wydawanych przez siebie książek. W 1930 r. deputowany do Reichstagu z Hessen-Darmstadt, wchodził w skład komisji do spraw zagranicznych. W okresie wojny - doradca A. Hitlera do spraw polityki zagranicznej bądź przewodniczący zagraniczno-politycznego komitetu frakcji NSDAP. Był pewny, że w rządzie utworzonym przez A. Hitlera obejmie stanowisko ministra spraw zagranicznych. Nigdy też nie mógł przeboleć, że Führer pominął go w 1933 r. i poza sprawami światopoglądowymi i polityczno-wychowawczymi powierzył mu jedynie funkcje bez znaczenia - szefa Wydziału Zagranicznego NSDAP. W kwietniu 1933 r. założył Biuro Pomocy Zagranicznej NSDAP (APA) i został kierownikiem Urzędu Polityki Zagranicznej NSDAP. Jednocześnie od stycznia 1934 do 1945 r. pełnomocnik Führera do spraw moralno-filozoficznej oświaty NSDAP. Od stycznia 1934 r. Reichsleiter NSDAP i zastępca Führera oraz kierownik NSDAP do spraw wychowania ideologicznego i polityki zagranicznej. SA- i SS-obergruppenführer. 29.01.1940 r. mianowany kierownikiem Narodowosocjalistycznego Centrum Badań Ideologicznych i Oświatowych. Organizował tak zwany Sztab Operacyjny Rosenberga. 20.04.1941 r. mianowany na pełnomocnika do spraw badania problemów przestrzeni Europy Wschodniej (Beauftragter für die zentrale Bearbeitung der Fragen des osteuropaischen Raumes). Od 17.07.1941 do 8.05.1945 r. minister Rzeszy Okupowanych Terenów Wschodnich. Główny ideolog hitlerowski i propagator teorii rasizmu i wyższości rasowej narodu niemieckiego. Jako minister pracował słabo: był biurokratą, brak mu było kompetencji i autorytetu w gronie podwładnych. Jego poglądów w sprawie bardziej liberalnej polityki na terenach wschodnich nie realizowano. $12.10 .1944 \mathrm{r}$. podał się do dymisji na znak protestu przeciw pertraktacjom z A. Własowem, na którą Hitler nawet nie odpowiedział. Wyrokiem Międzynarodowego Trybunału Wojennego w Norymberdze skazany na karę śmierci i 16.10 .1946 r. stracony.

51 „Karys”, 1989, nr 8, s. 358. 
Juozasa Pranckevičiusa czy policjanta 7. posterunku Jakutisa. Na szczęście, w porę dowiedziano się o planowanych przez dowództwo AK zamachach na dowódce policji w Wilnie i funkcjonariusza pochodzącego $\mathrm{z}$ rejonu orańskiego ${ }^{52}$.

Polscy partyzanci działali odważnie, ponieważ kierowała nimi niemiecka administracja. Naczelnik wileńskiego okręgu litewskiej policji bezpieczeństwa A. Lileikis zaświadczył, że litewska Sauguma miała nawet zdjęcia, stanowiące dowód na to, że w rejonie Soleczników funkcjonariuszy niemieckiej policji uzbrajały oddziały AK. Wszystkie napady polskich partyzantów były organizowane za wiedzą komisarza okręgu wileńskiego SS-sturmbannführera Horsta Wulffa ${ }^{53}$, gdyż jego głównym celem było podtrzymywanie niezgody między Litwą i Polską.

Niemcy, podburzając Litwinów przeciwko Polakom, równolegle szukali porozumienia z tymi ostatnimi, proponując prowadzenie wspólnej akcji przeciwko sowieckiej partyzantce. Warto zwrócić szczególną uwagę na postać dowódcy Abwehry na Litwie majora dr. Juliusa Christiansena ${ }^{54}$ oraz

52 Ibidem, 1991, nr 6, s. 321.

${ }^{53}$ Horst Wulff - ur. 28.10.1907 r. w Muhlheim (okręg Ruhry). Pierwszy raz wstapił do NSDAP 1.09.1926 r., drugi raz-1.10.1929 r. (nr 164 410). Przed wojną był funkcjonariuszem Głównego Urzędu Kadr SS, SS-obersturmbannführer. Od 28.07.1941 r. komisarz okręgu wileńskiego (Gebietskommissar Wilna-Land). 4.07.1944 r. samochodem uciekł z Wilna do Kowna. Generał SS Hintze rozkazał go aresztować i postawić przed sądem polowym, pod zarzutem popierania i systematycznego zaopatrywania w broń partyzantki polskiej. Przypisano mu zwłaszcza to, że w lutym i marcu 1944 r., gdy było już wiadomo, że partyzantka polska nawiązała kontakt i współpracę z partyzantką sowiecką i otrzymała tajne instrukcje wsparcia Armii Czerwonej - interweniował jeszcze na rzecz wypuszczenia aresztowanych przywódców band polskich, pod pretekstem tajnych rozmów z nimi; oraz że jeszcze w kwietniu tego roku dostarczył na dwóch ciężarówkach z „Wehrmacht-Fahrtbereitschaft-Wilna” broń ręczną i amunicję partyzantce polskiej w rejonie Puszczy Rudnickiej. Sąd polowy skazał go na karę śmierci przez rozstrzelanie. Za szkodliwe dla Niemiec popieranie Armii Krajowej z wyroku sądu rozstrzelany.

${ }^{54}$ Julius Christiansen - ur. 30.03.1897 r. na wyspie Sylt na Morzu Północnym. W jego rodzinie była polska gałąź. Do 1933 r. był deputowanym do Landtagu Prus jako poseł Niemieckiej Partii Ludowej ze Schleswig-Holstein. Przed wojną pracował w rezydenturze niemieckiego wywiadu i kontrwywiadu wojskowego (Abwehr) w Kopenhadze. Nie był narodowym socjalistą. Po zajęciu Czechosłowacji - kierownik Abwehry w Brnie. W 1941 r. zajął kolejne stanowisko we Francji w miasteczku Biaritz na wybrzeżu atlantyckim. 1.11.1942 r. został naczelnikiem 304. oddziału Abwehry (Abwehrkommando 304) w Wilnie. W 1944 r. na polecenie dowództwa wojsk lądowych prowadził rokowania z komendantem Armii Krajowej Okręgu Wilno A. Krzyżanowskim. W wyniku fiaska porozumienia ze stroną polską został odwołany ze swojego dotychczasowego obszaru działania i 1.05.1944 r. opuścił Litwę oraz został kierownikiem FAK 305 (Frontaufklärungskommando - oddział frontowego wywiadu) w Galicji, potem - w Krakowie. 1.04.1945 r. otrzymał stopień podpułkownika. Na terenie 
genezę rozmów niemiecko-polskich w Wilnie. W czasie debat z Polakami Christiansen oświadczył, że jeśli doszłoby do zawarcia porozumienia, „dałoby się przeprowadzić zastąpienie litewskiej administracji i policji przez polskie, gdyby Polacy wyrazili chęć zorganizowania takowej"55. Armia Krajowa miała stałego przedstawiciela w Abwehrstelle Wilna porucznika H. Borowskiego. Niemiecki komendant wojskowy Komisariatu Generalnego Litwa generał major Emil Just ${ }^{56}$ usiłował skierować walkę polskiego podziemia przeciwko partyzantom sowieckim. Już 8 stycznia 1944 roku niemiecka żandarmeria na obszarze Wilna nawiązała kontakt z oddziałami AK, chociaż takie pertraktacje były niezgodne z honorem AK-owca. Dnia 14 stycznia stosunki z Polakami nawiązały Wehrmacht i SD ${ }^{57}$. Podstawowe zadanie dowództwa niemieckiego polegało na zniszczeniu sowieckich oddziałów partyzanckich, do czego miały być użyte oddziały partyzanckie AK. Proponowano również AK podjęcie wspólnych z policją bezpieczeństwa i SD - działań przeciwko Armii Czerwonej oraz Armii Ludowej. Generał Just zaproponował dostarczenie Polakom broni i amunicji oraz wydał zalecenie litewskim jednostkom wojska i policji, aby przez pewien czas unikały ofensywnych działań przeciwko AK,

Protektoratu Czech i Moraw wpadł w ręce Sowietów i w 1950 r. zmarł w więzieniu w Rosji. Jego syn Heinrich Boy służył w jednostce Abwehry „Brandenburg”.

55 J. Wołkonowski, Wileńskie rozmowy niemiecko-polskie w lutym 1944 roku, „Mars”, (Warszawa-Londyn) 1994, t. 2, s. 192.

${ }^{56}$ Emil Just - ur. 18.06.1886 r. w Strasburgu. Wprawdzie nie znał języka litewskiego, lecz pochodził z rodziny Litwinów pruskich i swego litewskiego pochodzenia nie ukrywał. Rozpoczął służbę 7.05.1904 r. Od 1924 r. służył w Abwehrze. Od 15.05.1934 r. podpułkownik, od 1.03.1939 r. pułkownik. W okresie 15.09.1938-31.08.1940 attaché wojska i lotnictwa w Kownie i Rydze, kierownik rezydentury Abwehry w Kownie (tajna nazwa „Likog”). Dowodził tajną antysowiecką organizacją „Wojskowa Organizacja Litwy” („Lietuvos kariné organizacija”). Od 15.10.1940 r. attaché wojskowy w Rumunii. Po rozpoczęciu wojny - od 13.10.1941 r. komendant FK 821, komendant strefy bezpieczeństwa Komisariatu Generalnego Litwa (der Kommandant des Sicherungsgebietes Litauen), a od 1.11.1941 do 20.08.1944 r. główny wojskowy komendant polowy Litwy (Oberfeldkommandant-OFK 396), od 1.10.1942 r. generał major. Był życzliwy wobec Litwinów i zawsze starał się im pomóc. Pod koniec wojny popadł w niechęć nazistów, został zwolniony ze stanowiska i wysłany na front kurlandzki. Od 31.01.1945 r. w rezerwie. 3.05.1945 r. aresztowany w Berlinie przez Sowietów. Na procesie norymberskim jako świadek zeznawał na korzyść Litwy. W 1946 r. na procesie sądowym w Rydze świadczył przeciwko F. Jeckelnowi. 2.11.1946 r. w Wilnie skazany na śmierć, w lutym $1947 \mathrm{r}$. rozstrzelany w podziemiu budynku NKWD w Wilnie i potajemnie zakopany pod podłogą garażu w Tuskulenach.

${ }^{57}$ M. Foedrowitz, W poszukiwaniu ,, modus vivendi”. Kontakty i rozmowy pomiędzy okupantami a okupowanymi dotyczqce porozumienia niemiecko-polskiego w czasie II wojny światowej”, „Mars”, 1994, t. 2, s. 173. 
a nawet przypadkowych starć z nimi. W okręgu wileńskim między AK i Niemcami istniała umowa, że Niemcy będą płacić żołnierzom AK taką samą pensję jak litewskim policjantom, dostarczać im broń i żywność. W zamian żołnierze AK zobowiązali się do aktywniejszej walki z sowieckimi partyzantami, pilnowania dróg kolejowych, dostarczania Niemcom żywności od mieszkańców, którzy sabotowali dostawy albo nie zdołali ich wymusić funkcjonariusze litewskiej policji. Nieprzypadkowo niemiecka administracja, znająca dyslokację oddziałów AK, zakazała ich prześladowania zarówno wojsku niemieckiemu, jak i policji litewskiej. Gdy polscy żołnierze dostawali się w ręce policji litewskiej lub żołnierzy oddziałów Samoobrony, dowodzący nimi komisarz H. Wulff rozkazywał natychmiast zwalniać Polaków. Wszyscy litewscy policjanci znali srogi rozkaz komisarza okręgowego H. Wulffa: nie atakować polskich partyzantów ${ }^{58}$. Jednak równocześnie dowództwo niemieckie zdecydowało również, że rozmowy z Polakami nie mogą dotyczyć przekształceń politycznych Wileńszczyzny, chociaż istniał alternatywny plan. Latem 1944 roku Niemcy opracowywali projekt wspólnej z polskimi oddziałami obrony Wilna, przekazania administracji miasta w ręce Polaków, z możliwością oddania w przyszłości Wilna Polsce ${ }^{59}$.

Niemcy byli dobrze zorientowani w napiętych stosunkach polsko-litewskich. Starając się poróżnić Polaków i Litwinów, niemiecka administracja cywilna posłużyła się także prowokacją - rozpuściła plotki, że Litwini mszczą się na Polakach. Prasa podziemna informowała: „W ostatnim czasie Niemcy rozstrzelali 10 Polaków z Wileńskiego Kraju i około 100 wywieźli do obozu koncentracyjnego, obwieszczając, że zrobiono to za zabicie funkcjonariusza litewskiej policji kryminalnej Marianasa Padaby, chociaż zabity był urzędnikiem niemieckiego Gestapo"60.

W rzeczywistości Padaba był inspektorem policji litewskiej i stale podtrzymywał służbowy kontakt z siedzibą Gestapo w Wilnie. Marianas Padaba, mający pochodzenie białoruskie, dobrze znający języki polski i niemiecki, w 1939 roku po przekazaniu Wilna Litwie stał się agentem NKWD. Po wkroczeniu na Litwę Wehrmachtu przeszedł on do służby w Gestapo i często brał udział w przesłuchaniach aresztowanych Polaków,

\footnotetext{
58 J. Brazaitis, Vienu vieni, Vilnius 1990, s. 148.

59 E. Banasikowski, Na zew ziemi wileńskiej, Warszawa-Paryż 1990, s. 207.

60 „Lietuva”, 15 X 1943.
} 
za co przez dowództwo AK został skazany na karę śmierci i 15 września 1943 roku zastrzelony ${ }^{61}$.

Polacy jednak nadal pozostawali w konflikcie z Niemcami i z litewskim samorządem oraz policją. W związku z tym w drugiej połowie 1943 roku Niemcy podjęli masowe akcje pacyfikacyjne przeciwko Polakom - mieszkańcom Wileńszczyzny, wykorzystując do tego m.in. policję litewską. $\mathrm{W}$ terenie istniały jużjednak zorganizowane siły partyzanckie AK zdolne do podjęcia kontrakcji, przeważnie wówczas, gdy chodziło o małe siły wroga. W Trokach polscy partyzanci pobili kilku Litwinów, zastrzelili litewskiego sędziego, rozgrabili bank i napadli na litewską policję. Sadystycznie nastrojeni polscy partyzanci pojawili się w Turgielach, gdzie aresztowali nauczycielkę szkoły podstawowej, którą następnie poddali okrutnym torturom. Nie ominęli też Malat, gdzie zastrzelili czternastu Litwinów, a niedaleko Niemenczyna napadli na oddział policji litewskiej. W czasie bitwy zginęło sześćdziesięciu litewskich mężczyzn, reszta została wzięta do niewoli ${ }^{62}$. We wsi Michaliszki w gminie turgeliskiej w czasie bitwy z polskim oddziałem AK (200 mężczyzn) zginęło dziewiętnastu litewskich policjantów i siedmiu niemieckich żandarmów. Oddziały leśne AK 4 maja 1944 roku rozbiły w pobliżu Graużyszek dwie kompanie Miejscowej Drużyny Litwy, zabijając dwudziestu dwóch i biorąc do niewoli ośmiu Litwinów. W polskich odezwach głoszono: „Za jednego Polaka, dwudziestu Litwinów”. To tylko kilka przykładów zdarzeń, gdy Litwini ucierpieli na skutek działań żołnierzy AK.

W Wilnie obywatele pochodzenia polskiego swoją antypatię do Litwinów głosili powszechnie i bez skrępowania, posuwając się nawet do zaczepiania umundurowanych oficerów oddziałów Samoobrony oraz szeregowych policjantów, stojących na przykład w kolejce przy kasie kinowej. Dowódca oddziałów Samoobrony okręgu wileńskiego pułkownik Izidorius Kraunaitis ${ }^{63}$, dążąc do unikania nieporozumień z Polakami, był

${ }^{61}$ E. Banasikowski, op. cit., s. 153.

62 „Karys”, 1989, nr 8, s. 358.

${ }^{63}$ Izidorius Kraunaitis - ur. w 1899 r. Szkołę wojskową ukończył we Francji, kawalerzysta. Pułkownik sztabu generalnego wojska litewskiego, od początku wojny - naczelnik sztabu batalionów policyjnych. Od sierpnia 1941 r. - referent policji pomocniczej Departamentu Policji, od września 1941 r. - referent Samoobrony Departamentu Policji. Od 24.10.1941 do 30.09.1942 r. - dowódca batalionów policji okręgu wileńskiego. Jeden z kierowników Litewskiej Armii Wolności (LLA - Lietuvos laisvès armija). W 1944 r. wywiesił litewską flagę narodową na wieży zamku Giedymina w Wilnie. W latach 1944-1945 pracował w niemieckich szkołach wywiadu i dywersji. Po wojnie od 1949 r. mieszkał w USA, tam też zmarł. 
zmuszony poradzić funkcjonariuszom, aby w podobnych sytuacjach nosili zawsze ubrania cywilne ${ }^{64}$. Dopiero pod koniec wojny ten antagonizm nieznacznie się zmniejszył. W wielu miejscach, a w szczególności w okręgu wileńskim, za pośrednictwem funkcjonariuszy niemieckich, polscy partyzanci i litewska policja zawierali nawet umowy zobowiązujące każdą ze stron do nienapadania na siebie nawzajem i do wspólnej walki z bandami bolszewickich partyzantów ${ }^{65}$.

Polskie podziemie patrzyło na Związek Sowiecki łagodniej niż na Niemcy. W 1943 roku dowództwo AK skłaniało się ku temu, aby razem z Armią Czerwoną walczyć przeciwko Wehrmachtowi. Z kolei litewskie podziemie nie odrzuciło tym razem możliwości wspólnej z wojskiem niemieckim obrony przed inwazją armii radzieckiej, pod warunkiem, że polityczne kierownictwo Niemiec przyznałoby narodowi litewskiemu prawo do odtworzenia państwa i wojska. Litewskie podziemie w czasie wojny stosowało taktykę nieuzbrojonego oporu, a AK w 1943 roku zaczęła zbrojną walkę z Niemcami i Litwinami. Kiedy niemieckie próby pozyskania Polaków do walki z partyzantką sowiecką zawiodły, Niemcy zwróciły się do Litwy: na początku 1944 roku na mocy zgody Niemców na zwalczanie partyzantki polskiej i sowieckiej i na pełnienie innych funkcji policyjnych na terenie Litwy zaczęto organizować Miejscową Drużynę Litwy (Lietuvos vietine rinktine - LVR; Litauische Sonderverbände) ${ }^{66}$.

Drużyna, tworzona przez Niemców, ale pod litewskim dowództwem, miała stanowić zalążek armii litewskiej, która miała stawić czoło zbliżającej się do granic Litwy Armii Czerwonej. Projekt został aprobowany przez Kolegium Radców Generalnych i przyjęty entuzjastycznie przez społeczeństwo litewskie. Cel formowania drużyny był jeden: zatrzymać zbliżającą się armię sowiecką i po odejściu Niemców bronić odradzającego się niezależnego państwa litewskiego w granicach z 1940 roku wraz z Kłajpedą. Litewscy politycy mieli nadzieję na pozytywne efekty działalności LVR, mimo że kilka lat wcześniej ci sami działacze nie pozwolili swemu wojsku na choćby symboliczne sprzeciwienie się nadciagającemu

${ }^{64}$ LCVA, f. R-660, ap. 2, b. 246, 1. 3.

${ }^{65}$ Ibidem, f. R-685, ap. 5, b. 28, 1.1.

${ }^{66}$ Niektórzy polscy autorzy tę jednostkę nazywają „Litewskim korpusem posiłkowym” i „Litewskim miejscowym korpusem” (J. Wołkonowski), „Ochotniczym legionem litewskich nacjonalistow” i „Litewską formacją wojskową obrony terytorialnej” (R. Korab-Żebryk), „Litewskim Korpusem Pomocniczym”(„Karta” 1998, nr 24), „Litewskimi Oddziałami Miejscowymi” (J. Gdański), „Oddziałami Terytorialnymi” i „Litewskim korpusem terytorialnym” (J. Rutkiewicz). 
wojsku Związku Sowieckiego. Zakres działania LVR miał obejmować terytorium od Narwy do Wilna, a jej operacje na poczattkowym etapie musiały być skierowane przeciwko sowieckim partyzantom. Wielu znanych ludzi, sprzeciwiających się wcześniejszej mobilizacji, popierało teraz działania LVR, licząc na to, że stanowią one możliwość odtworzenia wojska narodowego Litwy. Jednostkę tę tworzono z poparciem podziemnych organizacji antynazistowskich i koordynującego ich działalność Głównego Komitetu Wyzwolenia Litwy (VLIK - Vyriausiasis Lietuvos išlaisvinimo komitetas). Była to kompromisowa decyzja Litwinów i Niemców. Jednak najpierw oddziały drużyny zajęły się oczyszczaniem kraju z partyzantów sowieckich i AK.

Antagonizm polsko-litewski przerodził się w zbrojny konflikt między batalionami policji litewskiej, a później - LVR, a oddziałami polskich partyzantów. Szczególnie wielką aktywnością odznaczył się powstały 15 maja 1943 roku w Kownie 253. batalion policji litewskiej. Jego główną funkcją było tłumienie działalności sowieckich i polskich partyzantów we wschodniej Litwie. $Z$ początku tymczasowo 253. batalionem policji litewskiej dowodził kapitan Vladas Aižinas ${ }^{67}$. Dnia 6 października 1943 roku został on wyznaczony na dowódcę 4 . kompanii tego batalionu. Od 1 czerwca do połowy lipca 1943 roku obowiązki dowódcy 253. batalionu policji tymczasowo pełnił kapitan Vladas Židžiūnas. Batalion był bezpośrednio podporządkowany dowódcy niemieckiej policji porządkowej przy dowództwie SS i policji na Litwie pułkownikowi żandarmerii Hansowi Hachtelowi ${ }^{68}$. Po krótkim szkoleniu w centrum szkoleniowym w Prenach batalion został ostatecznie sformowany w sierpniu i przerzucony do Kraju Wileńskiego w celu walki z ruchem partyzanckim i ochrony zbiorów. W tym czasie w batalionie służyło 10 oficerów, 29 oficerów kandydatów, 51 podoficerów oraz 350 policjantów, łącznie 440 osób $^{69}$. W skład powstającego batalionu zostało włączonych prawie dwustu ochotników, którzy zgłosili się do litewskiego legionu SS. Sztab batalionu mieścił się w Wilnie, na ulicy

${ }^{67}$ Vladas Aižinas - kapitan, służył w 14. i 255. batalionach policji litewskiej. W maju 1943 r. jako dowódca 4. kompanii tymczasowo dowodził 253. batalionem policji litewskiej. 6.10.1943 r. został mianowany dowódcą 4. kompanii tego batalionu.

${ }^{68}$ Hans Hachtel - ur. 25.10.1894 r. Doktor, pułkownik żandarmerii, w 1942 r. dowódca niemieckiej żandarmerii na Litwie. Od 22.09.1942 r. dowódca niemieckiej policji porządkowej przy dowództwie SS i policji na Litwie. Do września 1943 r. pełnił jednocześnie obowiązki inspektora litewskich jednostek Samoobrony.

${ }^{69}$ A. Bubnys, 253-iasis lietuviu policijos batalionas (1943-1944), „Genocidas ir rezistencija", 1998, nr 2 (4), s. 105. 
Ros, tym razem oddzielne kompanie były dyslokowane w Ejszyszkach, Oszmianie, Świrze oraz Trokach. W skład sztabu wchodziło 5 oficerów, 1 kandydat na oficera, 8 podoficerów oraz 11 żołnierzy ${ }^{70}$. Prawie przez cały czas walki z partyzantami batalionem skutecznie dowodził kapitan Vladas Žybas ${ }^{71}$. Wkrótce w celu wzmocnienia sił batalionu w jego skład włączono oddzielną kompanię (Sonderkompanie) o numerze 5.

Dnia 15 września ogłoszono rozkaz dowódcy policji porządkowej, aby przerwać ochronę zbiorów i wyjechać do Święcian. Tam batalion otrzymał zadanie ochrony byłej granicy litewsko-białoruskiej. W dniu 18 października w sztabie batalionu we wsi Buczany odbyła się narada dowódców jednostek policji litewskiej. Wziął w niej udział nawet sam wyższy dowódca SS i policji Ostlandu SS-obergruppenführer Friedrich Jeckeln ${ }^{72}$, który podziękował litewskim żołnierzom i oficerom za skutecznie przeprowa-

${ }^{70}$ LCVA, f. R-666, ap. 1, b. 8, 1. 125.

${ }^{71}$ Vladas Žybas - kapitan, od sierpnia 1943 do 28.04.1944 r. dowódca 253. batalionu policji.

${ }^{72}$ Friedrich Jeckeln - ur. 2.02.1895 r. w Hornbergu (Schwarzwald) w rodzinie fabrykanta. 1.10.1913 r. wstąpił do wojsk lądowych. Z początku jako szeregowy żołnierz brał udział w pierwszej wojnie światowej, w 1915 r. porucznik. W 1914 r. odznaczony Żelaznym Krzyżem II klasy. Po wojnie został członkiem korpusu ochotniczego. Od 1.10.1929 r. członek NSDAP (nr 163 348), od 15.03.1930 r. członek SS (nr 4367) i SS-sturmbannführer. Z wykształcenia architekt. Talent organizatorski. Od 22.06.1931 r. SS-standartenführer, od 20.09.1931 r. SS-oberführer. W okresie 31.03.1931-20.09.1931 dowódca 12. pułku SS. W okresie 20.09.1931-30.01.1933 dowódca SS-Abschnitt IV. Od 4.02.1933 r. SS-gruppenführer. W latach 1932-1943 deputowany do Reichstagu. W okresie 30.01.1933-15.07.1933 dowódca SS-Oberabschnitt „Sud”. Od 10.08.1933 r. dowódca SS trzech prowincji. W okresie kwiecień 1936-9.07.1940 dowódca, potem wyższy dowódca SS okręgu „Centr”. Od 13.09.1936 r. SS-obergruppenführer. 30.01.1939 r. otrzymał Złotą Odznakę Partyjną. W okresie maj-czerwiec 1940 dowódca 1. batalionu 2. pułku SS „Totenkopff”, brał udział w walkach we Francji. W okresie 12.07.1940-29.06.1941 wyższy dowódca SS i policji grupy „Zachód” (Düsseldorf). Od 1.04.1941 r. generał policji. Od 29.06.1941 do 1.11.1941 r. wyższy dowódca SS i policji odcinka „Rosja-Południe” i na Ukrainie, a od 1.11.1941 do maja 1945 r. - „Rosja-Północ”, od 12.12.1941 do marca 1945 r. - Ostlandu. Jednocześnie od 22.09.1944 do 18.01.1945 r. wyższy dowódca SS i policji „Belgien-Nordfrankreich”. 12.05.1942 r. odznaczony Żelaznym Krzyżem I klasy. 29.06.1942 r. otrzymał Ostmedaille. 19.12.1943 r. nagrodzony Złotym Krzyżem Niemieckim. Od 1.07.1944 r. generał Waffen-SS. 27.08.1944 r. nagrodzony Krzyżem Rycerskim Żelaznego Krzyża. W okresie marzec-maj 1945 dowódca V ochotniczego korpusu górskiego Waffen-SS (V SS-Freiwilligen-Gebirgs-Armee-Korps). 5.03.1945 r. jako 802 żołnierz Wehrmachtu nagrodzony Liśćmi Dębowymi do Krzyża Rycerskiego Żelaznego Krzyża. Odznaczony Honorową Szpadą i Pierścieniem Reichsführera SS (Ehrendegen des RF SS und Totenkopfring der SS). 2.05.1945 r. w Berlinie wpadł w ręce wojsk sowieckich. Wyrokiem wojskowego trybunału wojskowego okręgu nadbałtyckiego 3.02.1946 r. powieszony w Rydze. 
dzone akcje antypartyzanckie. Spora liczba policjantów 253. batalionu za odwagę i bohaterstwo $\mathrm{w}$ walce $\mathrm{z}$ sowieckimi i polskimi partyzantami została nagrodzona różnymi odznaczeniami.

Oficer łącznikowy litewskiej policji przy sztabie dowódcy niemieckiej policji porządkowej na Litwie V. Reivytis w lutym 1944 roku przygotował raport służbowy, przeznaczony dla dowódcy SS i policji na Litwie SS-brigadeführera i generała majora policji H. Harma, w którym opisał trudne położenie policji litewskiej w czwartym roku wojny ${ }^{73}$. W raporcie tym odnotowano, że 6 stycznia 1944 roku w policji litewskiej było zarejestrowanych 5734 funkcjonariuszy ${ }^{74}$, z których 71 osób chorowało albo było na urlopie, 964 osoby za różne przestępstwa i wykroczenia zostały aresztowane, 257 zdezerterowało, 849 pilnowało mostów strategicznych, gospodarstw, linii kolejowych albo wykonywało inną służbę, 510 zostało posłanych do oddziałów walczących z polskimi i sowieckimi partyzantami w okręgu wileńskim. $Z$ ogólnej liczby funkcjonariuszy policji trzeba byłoby wydzielić specjalną policję kolei, sztab policji, orkiestrę policji, wileńską szkołę policji, kowieński pododdział policji, który zajmował się szkoleniem policjantów, 664 policjantów, których zadaniem było werbowanie robotników do pracy w Niemczech. Czysto policyjną aktywność na początku 1944 roku prowadziło 2747 litewskich funkcjonariuszy. Siły policyjne były więc na tyle osłabione, że na niektórych posterunkach pozostały po 1-2 osoby. Im później, tym trudniej było policji litewskiej pełnić swoje obowiązki, a co dopiero walczyć z sowieckimi partyzantami. Główne siły policyjne - 2643 funkcjonariuszy - skupiono w okręgu wileńskim, gdzie aktywność sowieckich i polskich partyzantów była szczególnie nasilona.

Dowódca policji porządkowej przy dowództwie SS i policji na Litwie pułkownik lejtnant policji dr Walter Musil' 16 marca 1944 roku rozkazał dowódcom policji litewskiej, aby jej funkcjonariusze walczyli ze wszystkimi pojawiającymi się na Litwie partyzantami bolszewickimi i polskimi. Za niezdecydowanie w czasie walki policjant będzie oddawany pod polowy sąd wojskowy i karany śmiercią ${ }^{76}$. Dnia 16 marca 1944 roku telegramem

73 LCVA, f. R-683, ap. 2, b. 28, 1. 1-11.

74 Według innych źródeł archiwalnych, 6.01 .1944 r. w litewskiej policji służyło 5070 ludzi. Patrz ibidem, f. R-972, ap. 2, t. 2, b. 399, 1. 1-2.

75 Walter Musil - ur. 8.06.1894 r., Austriak. Doktor. Od 30.11.1942 r. podpułkownik policji. W latach 1943-1944 dowódca policji porządkowej przy dowództwie SS i policji na Litwie, jednocześnie od września 1943 r. inspektor litewskich jednostek Samoobrony.

76 LCVA, f. R-409, ap. 1, b. 23, 1. 72. 
nr 344a dyrektor Departamentu Policji V. Reivytis do odwołania anulował urlopy policjantów ${ }^{77}$.

Z chwilą pojawienia się batalionów LVR walki AK przeciwko nim na Wileńszczyźnie przybrały na sile. W maju 1944 roku doszło do krótkiejbo zaledwie dziesięciodniowej - ale intensywnej wojny pomiędzy litewskimi batalionami generała P. Plechavičiusa a partyzantami AK. Szczególnie niechlubnie zapisała się w historii stosunków polsko-litewskich trzecia dekada czerwca 1944 roku. W dniu 20 czerwca 1944 pod Glinciszkami doszło do starcia oddziału AK z jednostką policji litewskiej. Zginęło czterech Litwinów. W odwecie tego samego dnia stuosobowy oddział policji litewskiej zamordował 39 cywilnych mieszkańców Glinciszek, w tym kobiety i dzieci. Podejrzewano ich, że pomagali AK-owcom. Jednak za tę egzekucję wkrótce spotkała Litwinów kara - Niemcy aresztowali organizatorów napaści i rozstrzelali. Konsekwencją mordu w Glinciszkach był także atak 5. Brygady Wileńskiej AK na zamieszkane w większości przez Litwinów Dubinki. Zginęli nie tylko stacjonujący tam litewscy policjanci, ale i cywile, w tym, tak jak w Glinciszkach, kobiety i dzieci: w sumie 27 osób $^{78}$.

W czasie drugiej wojny światowej zginęło ponad 600 litewskich policjantów i żołnierzy batalionów policyjnych. Litewscy historycy ustalili nazwiska, daty i miejsca śmierci 498 funkcjonariuszy, którzy polegli przeważnie wskutek walki z polskimi formacjami.

Polscy historycy wciąż powtarzają tezę, że głównym celem batalionów LVR we wschodniej Litwie było prześladowanie polskich partyzantów i cywilów. Nie potwierdzają tego jednak dokumenty archiwalne. Przed wysłaniem batalionów LVR do wschodniej Litwy dowódca drużyny generał P. Plechavičius 26 kwietnia 1944 roku wydał rozkaz $\mathrm{nr} 8^{79}$ o porządku postępowania litewskich żołnierzy we wschodniej Litwie. Oto niektóre fragmenty tego rozkazu:

Komendantom powiatów i dowódcom batalionów rozkazuję wyjaśnić żołnierzom, że:

- Żołnierz Litwy musi być obrońcą nie tylko mówiących po litewsku mieszkańców kraju, ale i wszystkich innych uczciwych obywateli, bez względu na to, jakim językiem on mówi. [...]

${ }^{77}$ Ibidem, 1. 73.

78 A. Chmielarz, ZWZ-AK na Wileńszczyźnie, [in:] Lietuvos karybos istorijos klausimai (2), Kaunas 1994, s. 130.

${ }^{79}$ LCVA, f. R-1234, ap. 1, b. 2, 1. 9. 
- Żołnierz Litwy nie może poddawać się namowom różnych prowokatorów, którzy naumyślnie dążą do skłócenia żołnierza litewskiego z uczciwymi obywatelami Wileńskiego Kraju. [...]

- Wszyscy naruszyciele żołnierzy będą surowo karani, a prowokatorzy, którzy dążą do zepsucia dobrych stosunków żołnierzy z obywatelami [...] jako podrzegacze wojny domowej, będą karani śmiercią.

Jak pisze w swych wspomnieniach naczelnik sztabu LVR pułkownik Oskaras Urbonas ${ }^{80}$, dowództwo drużyny starało się unikać konfliktów z Polakami. W Kownie zaczęto życzliwiej spoglądać na borykające się w śmiertelnej walce $\mathrm{z}$ wrogiem społeczeństwo polskie. Zaczęto rozumieć i odczuwać skutki zaślepienia i błędnej polityki wobec swego naturalnego, historycznego sprzymierzeńca - Polski. Kierownictwo sztabu szukało możliwości nawiązania kontaktu $\mathrm{z}$ dowódcami polskiego podziemia. W tym celu generał P. Plechavičius włączył w skład sztabu LVR oficera do spraw specjalnych grafa Aleksandra Tyszkiewicza. Tego zamiaru nie zdążono jednak zrealizować ${ }^{81}$.

Kierownictwo polskiego podziemia zdawało sobie sprawę $\mathrm{z}$ tego, że skłócenie Polaków z Litwinami leży wyłącznie w interesie Niemiec. W kwietniu 1944 roku komendant AK okręgu wileńskiego pułkownik Aleksander Krzyżanowski wysłał list do generała P. Plechavičiusa z propozycją zawarcia umowy między AK i LVR o nieagresji i wstrzymania walk polsko-litewskich na Wileńszczyźnie; P. Plechavičiusa poproszono o wpłynięcie na administrację i policję litewską, aby nie prześladowały Polaków. LVR odrzuciła te propozycje i ogłosiła, że konflikt zbrojny jest nieunikniony, jeżeli AK pozostanie w Kraju Wileńskim. W odpowiedzi A. Krzyżanowski podkreślił, że AK walczy o niepodległość i integralność państwa polskiego i nie uznaje żadnych zmian terytorialnych, spowodowanych wojna, a mianowicie aneksji ziem wschodnich RP, dokonanej przez ZSRR, ani też „aneksji” Wilna i ziemi wileńskiej przez Litwinów.

\footnotetext{
${ }^{80}$ Oskaras Urbonas - ur. 31.03.1892 r. w Oszmincie, w powiecie mariampolskim. W 1914 r. ukończył szkołę artylerii w Petersburgu. Do 1927 r. dowódca 4. pułku artylerii. Od 1930 r. inspektor wojska Litwy, pułkownik. W 1944 r. naczelnik sztabu LVR. Wkrótce został aresztowany i znalazł się w obozie koncentracyjnym Salaspils, następnie-w Stutthofie. Po wojnie zamieszkał w Szwecji. Zmarł 5.11.1978 r.

${ }^{81}$ A. Bubnys, Lietuvos Vietinés Rinktinès susidurimai su Armija Krajowa 1944 metais, [in:] Lietuvos karybos istorijos, s. 135.
} 
Po rozwiązaniu LVR komendant AK okręgu wileńskiego pułkownik A. Krzyżanowski 15 maja wysłał powtórny list do generała P. Plechavičiusa, 17 maja do generała Stasysa Raštikisa ${ }^{82}$, a 20 maja ogłosił „Wezwanie do Litwinów", w którym całą winą za złe stosunki między oboma krajami obarczył Litwinów. Dalej dowódca AK przeszedł na ultymatywny ton i żądał:

1. Policja litewska i Sauguma (obecnie Gestapo), jak również urzędnicy litewscy muszą natychmiast zaprzestać wysługiwania się Niemcom na odcinku walki z Polakami. [...]

Cierpliwość nasza skończyła się. Jeżeli administracja, policja i Sauguma litewska nie zrozumieją tego wezwania i nie zaniechają takich metod walki, o s t r z e g a m, że zostanie zastosowany jak najostrzejszy kurs w stosunku do całej litewskiej policji, Saugumy i administracji i przy pomocy stojącej do mej dyspozycji Polskiej Siły Zbrojnej z n i s z c z ę w najbliższym czasie g n i a z d o z brodn i a r z y. [...] Wy - policjanci i saugumiści litewscy, jesteście zbrodniarzami, d o brow o ln i e i o c hotn i c z o stanęliście do walki z polskością na tej ziemi ${ }^{83}$.

Niestety, Litwini i Polacy pozostawali w konflikcie w czasach, gdy groziło im większe niebezpieczeństwo - Sowieci. A jednak w latach 1942 -1944 nie brakowało chęci, by powstałe problemy rozwiązywać na drodze rozmów pokojowych - podziemia litewskie i polskie wiele razy w czasie sekretnych narad próbowały znaleźć sposoby załagodzenia wzajemnej nienawiści i szukać kompromisu, rozumiejąc, że nie będzie niepodległej Litwy bez wolnego państwa polskiego. Sztaby AK systematycznie i uporczywie odmawiały jednak współdziałania z policją litewską w walce z partyzantami bolszewickimi.

Działania bojowe AK na ziemiach wschodnich Litwy od pierwszych miesięcy 1944 roku nabierały rozmachu - Polacy przygotowywali się do ostatecznego uderzenia. W okręgu wileńskim AK w ramach akcji „Burza” opracowano plan „Ostra Brama” mający na celu opanowanie stolicy Litwy Wilna w momencie zbliżania się frontu w okolice miasta i pokazanie światu, że Polacy umieją sami się wyzwalać i że Wilno musi przynależeć do Polski. W tych warunkach społeczeństwo polskie na Wileńszczyźnie, które doskonale znało zamiary Moskwy wobec narodu polskiego, z przerażeniem

\footnotetext{
${ }^{82}$ Urodził się 13.09.1896 r., zmarł 3.05.1985 r.

${ }^{83}$ R. Korab-Żebryk, Biała księga w obronie Armii Krajowej, s. 116.
} 
obserwowało cofający się front niemiecki i z wielką bojaźnią podchodziło do zapowiedzianej współpracy AK ze zbliżającą się Armią Czerwoną.

Na podstawie rozkazu Adolfa Hitlera Fuhrerbefehl Nr. 11 wydanego 8 marca 1944 roku Wilno miało być ufortyfikowane i przygotowane do długiej obrony jako twierdza. Zmobilizowano siłę roboczą do wykonania prac ziemnych i betonowych w planowanej sieci bunkrów w promieniu 5-7 km od centrum miasta. Do Wilna przyjechał z Niemiec specjalista fortyfikator, który rozpoczął prace w kwietniu.

Uderzenie AK na Wilno rozpoczęło się w nocy z 6 na 7 lipca 1944 roku siłą 17000 żołnierzy. Jednak nierówna walka oddziałów partyzanckich z wyposażoną w ciężką broń regularną armią niemiecką stała się początkiem tragedii. Podjęte rano 7 lipca kontrnatarcie niemieckie zmusiło oddziały AK do wycofania się. W celu obrony Wilna, w składzie grupy bojowej „Schmidt”, Niemcy skierowali znany batalion spadochronowy - 500./600. SS-Fallschirmjager Battalion (dowódca SS-hauptsturmführer Kurt Rybka). Dnia 7 lipca dwie kompanie i sztab II batalionu 16. pułku strzelców spadochronowych (dowódca podpułkownik Gerhard Schirmer) ${ }^{84}$ zostały przetransportowane samolotami Ju-52 na lotnisko wileńskie w Porubanku. Były to najlepsze jednostki, jakimi dysponowała Trzecia Rzesza. Wszyscy żołnierze byli fanatycznymi nazistami, pochodzili z zaciągu ochotniczego. Żaden z nich nie miał więcej niż 25 lat. Zostali przygotowani do walki w każdych warunkach, chlubili się swoim przezwiskiem „zielone diabły”.

Polakom udało się utrzymać zdobyte pozycje tylko na Belmoncie, części dzielnicy kalwaryjskiej, Wzgórzach Szeszkińskich, gdzie od razu rozpoczęły się przeczesywania mieszkań w poszukiwaniu Litwinów. Od 8 do 13 lipca oddziały AK walczyły o Wilno razem z jednostkami okupanta ziem polskich i wroga Polaków Armii Czerwonej, gdyż otrzymali od sowieckiego dowództwa gwarancje bezpieczeństwa. Walka oddziałów AK o Wilno pozwoliła Sowietom doskonale rozpoznać siły nieprzyjaciela i ich dyslokację. Dnia 13 lipca Wilno skapitulowało, do obrony Kowna przerzucono zaś drogą lotniczą doborowe oddziały SS. Tym razem współpraca

${ }^{84}$ Gerhard Schirmer - ur. 9.01.1913 r. w Chemnitz (Sachsem). 14.06.1941 r., jako kapitan i dowódca kompanii 2. pułku spadochroniarzy, nagrodzony Krzyżem Rycerskim Żelaznego Krzyża. Podpułkownik, dowódca 16. pułku spadochroniarzy. 7.07.1944 r. razem ze swymi żołnierzami desantował się na ulicy Wilna i bronił stolicy Litwy. W końcu października $1944 \mathrm{r}$. przerzucony do Kłajpedy, gdzie za bohaterstwo 18.11.1944 r. jako 657 żołnierz Wehrmachtu został nagrodzony Liśćmi Dębowymi do Krzyża Rycerskiego Żelaznego Krzyża. Od 1.12.1956 do 31.03.1971 r. pułkownik Bundeswehry. 
Polaków z Rosjanami zakończyła się dramatycznie: Polakom nie pozwolono przejść marszem przez miasto, w oficjalnym komunikacie Rosjanie za pomoc i współpracę „podziękowali” żołnierzom polskim, a 17 lipca pułkownik A. Krzyżanowski „Wilk” wraz ze swym najbliższym sztabem został aresztowany w Wilnie. Wraz z przybyciem Armii Czerwonej terror ponownie nasilił się na Wileńszczyźnie. O stolicę Litwy walczyło 350 tysięcy żołnierzy - Niemców, Polaków, Rosjan, tylko, niestety, wśród nich kolejny raz nie było Litwinów.

Litwini i Polacy stanęli przeciwko sobie w chwili, gdy zagrażali im o wiele bardziej niebezpieczni wrogowie. Konflikt między policją litewską i Polakami nie dał oczekiwanej korzyści ani jednej, ani drugiej stronie. Wygrała trzecia siła - rosyjski bolszewizm, który zlikwidował zarówno polskie, jak i litewskie podziemie niepodległościowe. Dziś nadszedł czas, by oba narody wybaczyły sobie wzajemnie wyrządzone krzywdy, prawdziwe i być może wymyślone. O wydarzeniach tych należy pamiętać jedynie po to, by następne pokolenia czerpały naukę z historii i nigdy nie występowały przeciwko sąsiadowi Litwinowi czy Polakowi. Historii nie da się zmienić, a w stosunkach polsko-litewskich ważniejsze są teraźniejszoość i przyszłość, a nie przeszłość.

Nie ma narodów obdarowanych dobrą pamięcią i nie ma społeczności skazanych na pamięć złą. To my wybieramy swoją historię w zależności od tego, jaka jest nasza kondycja społeczna. Na zakończenie wspomnijmy słowa litewskiego pisarza, doktora honoris causa uniwersytetu toruńskiego, Tomasa Venclovy, wypowiedziane w 1994 roku w Zagrzebiu:

W żadnym wypadku nie stymulować i nie usprawiedliwiać mordów, co oznacza: nigdy nie wynosić interesów swojego narodu ponad prawa człowieka, nigdy nie upiększać swojej historii, nigdy nie zapominać i nie usprawiedliwiać swojej winy, nawet jeżeli wina sąsiada albo wroga wydaje się bądź w rzeczywistości jest większa od twojej; nigdy nie stosować podwójnego standardu, nawet jeżeli stosuje go sąsiad lub przeciwnik. Ogółem, zostawić sąsiadowi jego grzechy do wytłumaczenia, a samemu wytłumaczyć się ze swoich. Zatem, sprzeciwiać się pysze, złej woli, przemilczaniu niewygodnych faktów, nawet jeżeli zmusza to do walki z władzą własnego kraju albo, jeszcze gorzej, z opiniami i emocjami, panującymi wśród większości narodu ${ }^{85}$.

85 „Lietuviu-Zydu santykiai. Istoriniai, teisiniai ir politiniai aspektai” Praktinis seminaras - diskusija. Stenograma, Vilnius 1999, s. 50. 
Policja litewska i sprawy polskie na ziemiach litewskich...

\section{Lithuanian police and Polish affairs in Lithuanian lands in 1939-1944 (summary)}

When the war broke out, refugees from Poland flooded Lithuania. This is probably a unique case when people who despised others fled to them in order to save their own lives. Confrontation between Lithuanians and Poles started growing in 1941, when Wehrmacht entered the territory of Lithuania. Chauvinistic sentiments were particularly marked by reactionary Polish nationalists, who acted fairly widely in individual German institutions in Vilnius and established the so-called local selfgoverning bodies in individual areas of Vilnius Region, the Polish auxiliary police was set up.

Lithuanian and Polish contradictions for a long time did not result in any major confrontation. However, a conflict was inevitably coming to a head. As soon as Germans took power into their hands they tried to exploit contradictions between Lithuanians and Poles. In 1942, an effort was made to foster hostility between Lithuanians and Poles by evicting from Eastern Lithuania the so-called statistical Poles. Lithuanian officers were to confirm the eviction with their signatures and Lithuanian policemen were to conduct eviction. The German administration supported and well armed the Polish guerillas who raged in areas of the Švenčionys County, terrorizing and killing Lithuanians and attacking the Lithuanian police. The Lithuanian security service even had photographs showing how German police officers armed Armia Krajowa (AK) squads in the Šalčininkiai District.

The animosity between the Lithuanians and Poles somewhat decreased only when the war was coming to an end. In many places and Vilnius District in particular an agreement mediated by German officers was reached between the Polish guerillas and the Lithuanian police not to attack each other and to fight together against Bolshevik guerilla gangs. In 1943, AK leadership tended jointly with the Red Army to fight against the German Wehrmacht, whereas the Lithuanian Resistance movement did not reject the possibility of defending against the invasion by the Red Army together with the German army if the German political leadership recognized the right of the Lithuanian people to restore their state and army. Nevertheless in 1942-1944 the Lithuanian and Polish underground Resistance movements in numerous secret discussions tried to mitigate the mutual hatred and to look for compromises. 
(cC) $(9)$ 